\title{
Novel Chrysin-De-Allyl PAC-1 Hybrid Analogues as Anticancer Compounds: Design, Synthesis, and Biological Evaluation
}

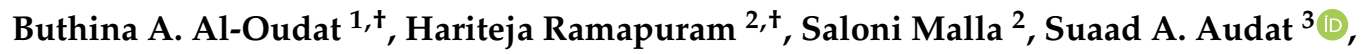 \\ Noor Hussein ${ }^{2}$, Jenna M. Len ${ }^{2}$, Shikha Kumari ${ }^{4}$, Mel F. Bedi ${ }^{5}\left(\mathbb{D}\right.$, Charles R. Ashby, Jr. ${ }^{6}$ and \\ Amit K. Tiwari ${ }^{2, *(\mathbb{D})}$ \\ 1 Department of Medicinal Chemistry and Pharmacognosy, Faculty of Pharmacy, Jordan University of Science \\ and Technology, P.O. Box 3030, Irbid 22110, Jordan; baoudat@just.edu.jo \\ 2 Department of Pharmacology and Experimental Therapeutics, College of Pharmacy \& Pharmaceutical \\ Sciences, University of Toledo, Toledo, $\mathrm{OH}$ 43614, USA; hzr0030@tigermail.auburn.edu (H.R.); \\ saloni.malla@rockets.utoledo.edu (S.M.); noor.hussein@rockets.utoledo.edu (N.H.); \\ jenna.len@rockets.utoledo.edu (J.M.L.) \\ 3 Department of Chemistry, College of Science and Arts, Jordan University of Science and Technology, \\ P.O. Box 3030, Irbid 22110, Jordan; saaudat@just.edu.jo \\ 4 Department of Pharmaceutical Sciences, College of Pharmacy, University of Nebraska Medical Center, \\ Omaha, NE 68198, USA; fnu.shikha@unmc.edu \\ 5 Department of Medicinal and Biological Chemistry, College of Pharmacy \& Pharmaceutical Sciences, \\ University of Toledo, Toledo, OH 43614, USA; Fernand.Bedi@utoledo.edu \\ 6 Department of Pharmaceutical Sciences, College of Pharmacy \& Pharmaceutical Sciences, \\ St. John's University, Queens, NY 11439, USA; cnsratdoc@optonline.net \\ * Correspondence: Amit.Tiwari@UToledo.edu; Tel.: +1-419-383-1913; Fax: +1-419-383-1909 \\ + These authors contributed equally to this work.
}

Academic Editor: Qiao-Hong Chen

Received: 2 June 2020; Accepted: 30 June 2020; Published: 4 July 2020

\begin{abstract}
New chrysin-De-allyl-Pac-1 hybrid analogues, tethered with variable heterocyclic systems (4a-4o), were rationally designed and synthesized. The target compounds were screened for in vitro antiproliferative efficacy in the triple-negative breast cancer (TNBC) cell line, MDA-MB-231, and normal human mammary epithelial cells (HMECs). Two compounds, $4 \mathrm{~g}$ and $\mathbf{4 i}$, had the highest efficacy and selectivity towards MDA-MB-231 cells, and thus, were further evaluated by mechanistic experiments. The results indicated that both compounds $4 \mathrm{~g}$ and $4 \mathbf{i}$ induced apoptosis by (1) inducing cell cycle arrest at the G2 phase in MDA-MB-231 cells, and (2) activating the intrinsic apoptotic pathways in a concentration-dependent manner. Physicochemical characterizations of these compounds suggested that they can be further optimized as potential anticancer compounds for TNBC cells. Overall, our results suggest that $4 \mathrm{~g}$ and $4 \mathbf{i}$ could be suitable leads for developing novel compounds to treat TNBC.
\end{abstract}

Keywords: triple-negative breast cancer; cytotoxicity; chrysin analogues; flavonoid; anticancer compounds

\section{Introduction}

Breast cancer is the second leading cause of death among all cancers affecting women [1]. Triple-negative breast cancer (TNBC) lacks the expression of hormone receptors (estrogen (ER) or progesterone (PR)) and/or human epidermal growth factor receptor 2 (HER2), which are more amenable to targeted therapy [2]. TNBC often presents as a high-grade invasive ductal carcinoma (IDC) in 
patients, accounting for one-fourth of all breast cancer deaths. Consequently, there is an urgent need for the development of compounds that are efficacious and safe for the treatment of breast cancer. Flavonoids are ubiquitous naturally occurring polyphenolic compounds that are commonly found in fruits and vegetables [3]. Flavonoids comprise several classes of low molecular weight compounds, including flavanones, anthocyanidins, flavonols, flavanols, isoflavones, dihydroflavonols, and flavones [4-6]. Chrysin (5, 7-dihydroxyflavone, Figure 1) is a natural flavone found in many plant extracts, such as the blue passionflower, as well as in honey and propolis [7,8]. Chrysin has been reported to have properties, such as antioxidant [9], antihypertensive [10], antibacterial [11], anti-inflammatory [12], antiviral [13], antiallergic [14], antidiabetic [15], anxiolytic [16], and anticancer efficacy $[17,18]$. The activation of apoptosis plays a major role in producing the anticancer efficacy of chrysin [19-21]. Mechanistically, apoptosis involves a cascade of initiator and effector caspases [22]. Among these caspases, caspase-3 and caspase-7 are downstream executioner caspases that play an essential role in inducing apoptosis by cleaving a variety of cellular substrates [23]. Therefore, caspase-dependent apoptosis pathways represent targets for the development of efficacious anticancer drugs. Recently, a number of studies have been done to augment the pharmacological activity of chrysin by producing synthetic analogues [24-29]. Moreover, there are studies indicating that chrysin-based compounds have in vitro efficacy in breast cancer cells [30-32]. The compound, de-allyl procaspase-activating compound 1 (PAC-1), induces apoptosis in different types of cancer cells by activating caspase-3 and/or caspase-7 [33-36]. Previously, we reported that molecular hybridization between chrysin and de-allyl PAC-1 can be used to produce novel hybrid molecules with cytotoxic efficacy [29]. Molecular hybridization is a process that comprises the amalgamation of two or more pharmacophoric moieties of different bioactive molecules into a single molecular framework [37,38].

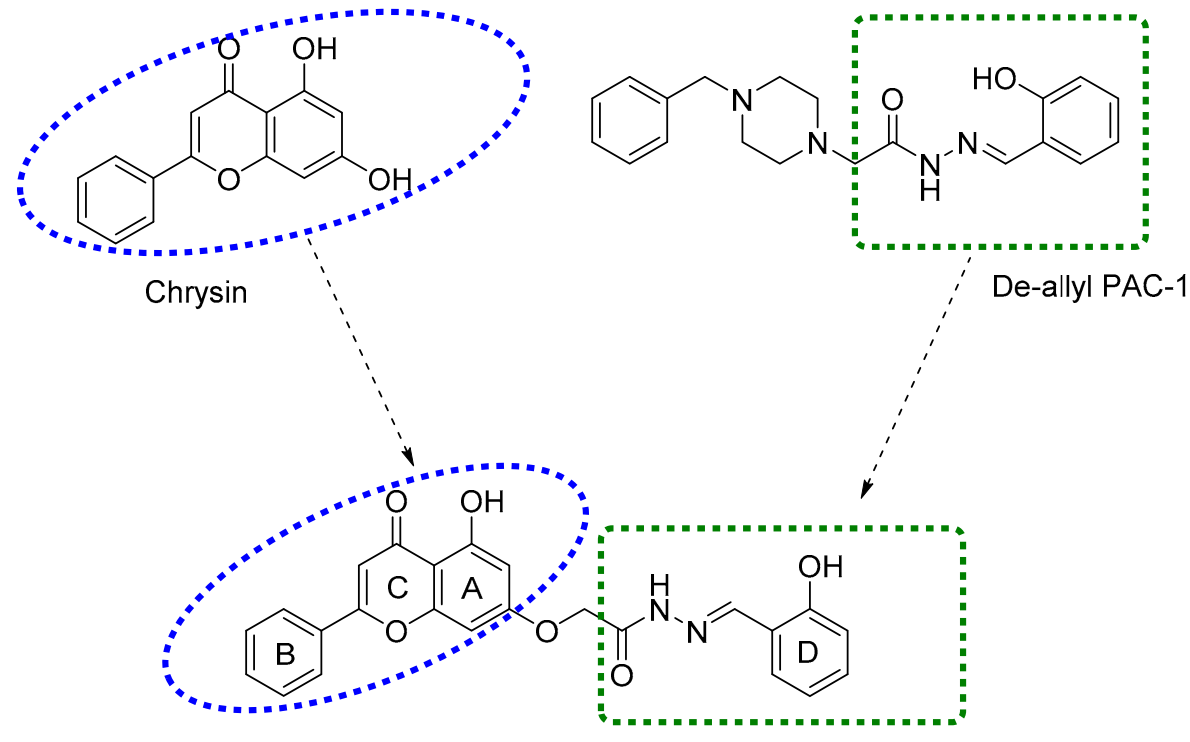

Representative designed hybrid molecule $\mathbf{4 a}$

Figure 1. Chemical structures of chrysin, de-allyl PAC-1, and a representative designed hybrid molecule 4 a.

In this study, new chrysin-de-allyl PAC-1 hybrid analogues, substituted with variable aromatic heterocyclic cores, were synthesized and evaluated to identify a more potent bioactive hybrid against breast cancer cells (Figure 1). The in silico parameters of the synthesized compounds were calculated to predict their pharmacokinetic profile and drug-likeness using SwissSimilarity ADME, a web tool [39]. Subsequently, the target compounds were screened for antiproliferative efficacy in the human breast cancer cell line MDA-MB-231, using the MTT 3-(4,5-Dimethylthiazol-2-yl)-2,5-Diphenyltetrazolium 
Bromide) colorimetric assay. Finally, we determined the effects of the most potent compounds on the cell cycle.

\section{Results and Discussions}

\subsection{Chemistry}

The target compounds (4a-4o) were prepared according to Scheme 1, starting from the commercially available chrysin, using previously published synthetic procedures [29]. Briefly, chrysin was added to methyl 2-bromoacetate at a low temperature in the presence of $\mathrm{K}_{2} \mathrm{CO}_{3}$, yielding the desired alkylation product 2 . The conversion of ester 2 into hydrazide 3 was accomplished using $80 \%$ hydrazine hydrate and a few drops of hydrochloric acid at low temperature. ${ }^{1} \mathrm{H}$ and ${ }^{13} \mathrm{C}$ NMR data confirmed the formation of hydrazide 3 as a pure single product. Target compounds (4a-4o) were obtained by adding hydrazide 3 to an appropriate aldehyde in the presence of a catalytic amount of hydrochloric acid at room temperature. All analogues gave adequate analytical and spectroscopic data, which were in full accordance with their structures. ${ }^{1} \mathrm{H}$ and ${ }^{13} \mathrm{C}$ NMR spectra showed that compounds 4a-4o existed as geometrical isomers (E/Z isomers). The $\mathrm{E}: \mathrm{Z}$ ratio for each compound was determined from ${ }^{1} \mathrm{H}$ NMR spectra utilizing the integration of the neat methylene group peaks that appeared as two separated singlets for each isomer. Target compounds were analyzed using SwissSimilarity (Swiss Institute of Bioinformatics, Lausanne, Switzerland). Compounds $\mathbf{4 a}-\mathbf{4 j}$ and $\mathbf{4 n}-\mathbf{4 o}$ were the most structurally similar to apigenin, a flavonoid similar to chrysin. The physicochemical properties of the compounds (4a-4o) are shown in Table 1.<smiles>CC(C)C</smiles>

1<smiles>COC(=O)COc1cc(O)c2c(=O)cc(-c3ccccc3)oc2c1</smiles><smiles>NNC(=O)COc1cc(O)c2c(=O)cc(-c3ccccc3)oc2c1</smiles><smiles>CCCC</smiles><smiles>[R]C=NNC(=O)COc1cc(O)c2c(=O)cc(-c3ccccc3)oc2c1</smiles>

Scheme 1. Reagents and conditions: (a) methyl 2-bromoacetate, $\mathrm{K}_{2} \mathrm{CO}_{3}, \mathrm{DMF}, 0^{\circ} \mathrm{C}, 3 \mathrm{~h}$; (b) hydrazine hydrate $80 \%, \mathrm{EtOH}, 0{ }^{\circ} \mathrm{C}, \mathrm{HCl}$ (cat.), 1 h; (c) different substituted aldehydes, $\mathrm{CH}_{3} \mathrm{OH}, \mathrm{HCl}$ (cat), rt, 1 h.

Table 1. Physiochemical properties of the compounds $\mathbf{4 a - 4 o}$ collected from Swiss ADME.

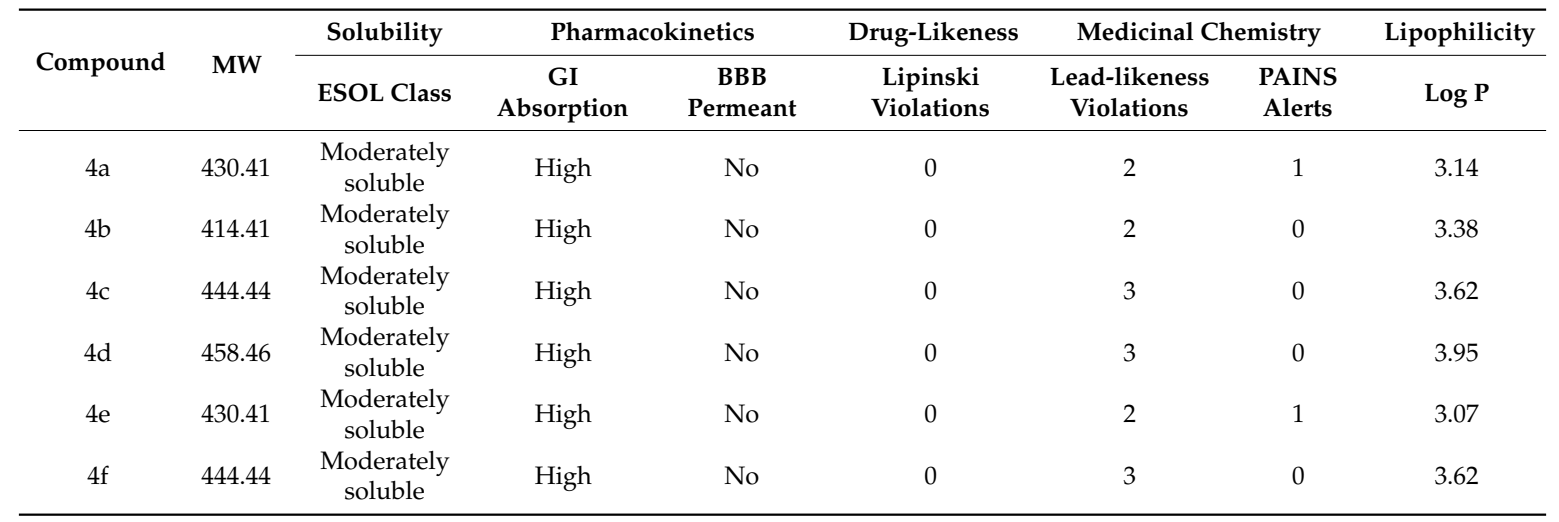


Table 1. Cont.

\begin{tabular}{|c|c|c|c|c|c|c|c|c|}
\hline \multirow{2}{*}{ Compound } & \multirow{2}{*}{ MW } & \multirow{2}{*}{$\begin{array}{l}\text { Solubility } \\
\text { ESOL Class }\end{array}$} & \multicolumn{2}{|c|}{ Pharmacokinetics } & \multirow{2}{*}{$\begin{array}{c}\text { Drug-Likeness } \\
\text { Lipinski } \\
\text { Violations } \\
\end{array}$} & \multicolumn{2}{|c|}{ Medicinal Chemistry } & \multirow{2}{*}{$\begin{array}{c}\text { Lipophilicity } \\
\log P\end{array}$} \\
\hline & & & $\begin{array}{c}\text { GI } \\
\text { Absorption }\end{array}$ & $\begin{array}{c}\text { BBB } \\
\text { Permeant }\end{array}$ & & $\begin{array}{l}\text { Lead-likeness } \\
\text { Violations }\end{array}$ & $\begin{array}{l}\text { PAINS } \\
\text { Alerts }\end{array}$ & \\
\hline $4 \mathrm{~g}$ & 446.41 & $\begin{array}{l}\text { Moderately } \\
\text { soluble }\end{array}$ & Low & No & 0 & 2 & 2 & 2.71 \\
\hline $4 h$ & 474.46 & $\begin{array}{l}\text { Moderately } \\
\text { soluble }\end{array}$ & High & No & 0 & 3 & 0 & 3.65 \\
\hline $4 \mathrm{i}$ & 462.41 & $\begin{array}{l}\text { Moderately } \\
\text { soluble }\end{array}$ & Low & No & 0 & 2 & 3 & 2.38 \\
\hline $4 j$ & 462.41 & $\begin{array}{c}\text { Moderately } \\
\text { soluble }\end{array}$ & Low & No & 0 & 2 & 2 & 2.43 \\
\hline $4 k$ & 404.37 & $\begin{array}{l}\text { Moderately } \\
\text { soluble }\end{array}$ & High & No & 0 & 2 & 0 & 2.81 \\
\hline 41 & 415.4 & $\begin{array}{l}\text { Moderately } \\
\text { soluble }\end{array}$ & High & No & 0 & 2 & 0 & 2.66 \\
\hline $4 \mathrm{~m}$ & 415.4 & $\begin{array}{l}\text { Moderately } \\
\text { soluble }\end{array}$ & High & No & 0 & 2 & 0 & 2.72 \\
\hline $4 \mathrm{n}$ & 480.47 & $\begin{array}{l}\text { Poorly } \\
\text { soluble }\end{array}$ & Low & No & 0 & 2 & 1 & 4.04 \\
\hline 40 & 475.41 & $\begin{array}{l}\text { Moderately } \\
\text { soluble }\end{array}$ & Low & No & 1 & 3 & 1 & 2.52 \\
\hline
\end{tabular}

ESOL Class: Estimated Solubility Class [40]. GI Absorption: Gastrointestinal Absorption. BBB Permeant: Blood Brain Barrier Permeant. Lipinski Violations examines orally active compounds to determine ranges for high probability to be an oral drug. Lead-likeness Violations examines compounds' likeliness to become a lead based on a rule-based method [41]. PAINS Alerts: compounds that give false positives where the compound nonspecifically binds to numerous biological targets, instead of one desired target [42]. Log P: partition coefficient measuring lipophilicity [41].

\subsection{3-(4,5-Dimethylthiazol-2-yl)-2,5-Diphenyltetrazolium Bromide-Based Cytotoxicity Assay}

The synthesized chrysin derivatives were evaluated for cytotoxic efficacy in the human breast cancer cell line, MDA-MB-231, using the 3-(4,5-dimethylthiazol-2yl)-2,5-diphenyltetrazolium bromide (MTT) colorimetric assay and doxorubicin was used as a reference anticancer drug. The $\mathrm{IC}_{50}$ values (concentration of compound in $\mu \mathrm{M}$ required to reduce $50 \%$ of cell viability) are shown in Table 2 .

Table 2. The effects of chrysin derivatives (4a-4o) on the survival of the MDA-MB-231 cancer cell line.

Compound


Table 2. Cont.

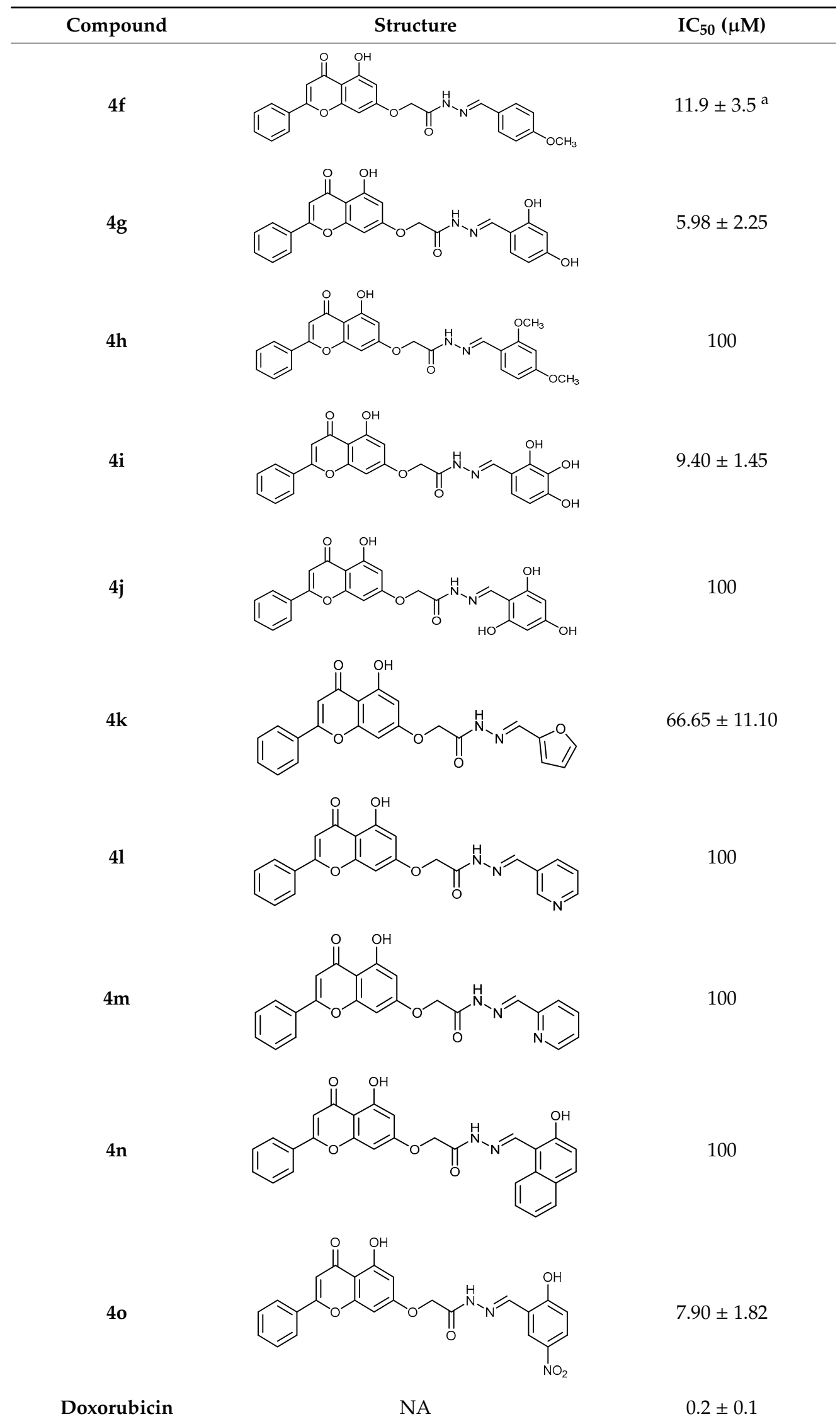

Cell survival was determined by MTT assay as described in materials and methods. The $\mathrm{IC}_{50}$ values are represented as mean $\pm \mathrm{SD}$ of two independent experiments performed in triplicate. ${ }^{\text {a }}$ The data was taken from [29]. 
As shown in Table 2, the structure-activity relationship (SAR) results indicated that the cytotoxic efficacy of the synthesized compounds was affected by the modifications on the benzene ring (ring D) of the parent compound $4 \mathbf{a}$. Compound $4 \mathbf{a}$, possessing a hydroxyl group at C-2 of ring D, had cytotoxic efficacy, with an $\mathrm{IC}_{50}$ value of $6.8 \mu \mathrm{M}$. To determine the importance of the hydroxyl group at the C-2 position, compound $\mathbf{4 b}$ was synthesized, and its efficacy was similar to compound $4 \mathbf{a}$. The methylation of the hydroxyl group in $4 \mathbf{a}$ yielded compound $4 \mathbf{c}$, which had a lower efficacy than $4 \mathbf{a}$ and $\mathbf{4 b}$, whereas ethylation of the hydroxyl group, which yielded compound $\mathbf{4 d}$, produced a significant decrease in cytotoxic efficacy, compared to compound 4a. Previously, we reported that the shifting of the hydroxyl group from C-2 to C-4 (4e) produced a significant reduction in the cytotoxic efficacy $\left(\mathrm{IC}_{50}>50 \mu \mathrm{M}\right)$. However, methylation of the hydroxyl group in $4 \mathbf{e}$ yielded compound $4 \mathbf{f}$, which was $\sim 5$ times more efficacious than $4 \mathbf{e}$ [29]. The addition of a second hydroxyl group at the C-4 position in $4 \mathbf{a}$ resulted in compound $4 \mathbf{g}\left(\mathrm{IC}_{50}=5.98 \mu \mathrm{M}\right)$, which had cytotoxic efficacy similar to compound $4 \mathbf{a}$. Interestingly, the methylation of the two hydroxyl groups in $4 \mathbf{g}$, yielding compound $4 \mathrm{~h}$, significantly decreased the cytotoxic efficacy. The addition of a third hydroxyl group to $4 \mathrm{~g}$ at position 3 of ring $\mathrm{D}$, yielding compound $4 \mathbf{i}$, did not significantly alter the antiproliferative efficacy of the compound, whereas adding a third hydroxyl group at position 6 of ring D yielded a totally inactive compound, $\mathbf{4 j}$. Next, we determined the effect of ring D on the cytotoxic efficacy of the synthesized compounds. Therefore, compounds $\mathbf{4 k}-\mathbf{4 m}$ were synthesized, where ring $\mathrm{D}$ was replaced with aromatic heterocyclic moieties. Compounds $4 \mathbf{k}, 4 \mathbf{1}$, and $4 \mathrm{~m}$, containing furan, 3-pyridine, and 2-pyridine moieties, respectively, did not have significant cytotoxic efficacy. Furthermore, adding another fused benzene ring to ring $\mathrm{D}$, while keeping the C-2 hydroxyl group (2-hydroxynaphthalene), yielded the inactive compound, $\mathbf{4 n}$. The addition of a nitro group at the C5-position of ring D in $4 \mathbf{a}$ yielded compound $4 \mathbf{0}$, which had an efficacy similar to compound $4 \mathbf{a}\left(\mathrm{IC}_{50}=7.9 \mu \mathrm{M}\right)$.

Next, the cytotoxicity and selectivity of the most active compounds, $\mathbf{4} \mathbf{g}$ and $\mathbf{4 i}$, were determined in a panel of cell lines, including the normal cell lines, HMECs, and cancer cell lines, BT-20, U-251, and HCT116, as shown in Figure 2 and Table 3. Compound $4 \mathrm{~g}$ had antiproliferative efficacy in the BT-20, $\mathrm{U}-251$, and HCT116, with $\mathrm{IC}_{50}$ values of 5.32, 7.64, and 2.68, respectively. In contrast, compound $4 \mathbf{i}$ had $\mathrm{IC}_{50}$ values ranging from 10-25 $\mu \mathrm{M}$. The results indicated that although compound $4 \mathrm{~g}$ is more potent than compound $4 \mathbf{i}$ in the three cancer cell lines, compound $4 \mathbf{i}$ is more selective for the cancer cells than the normal cells.

A
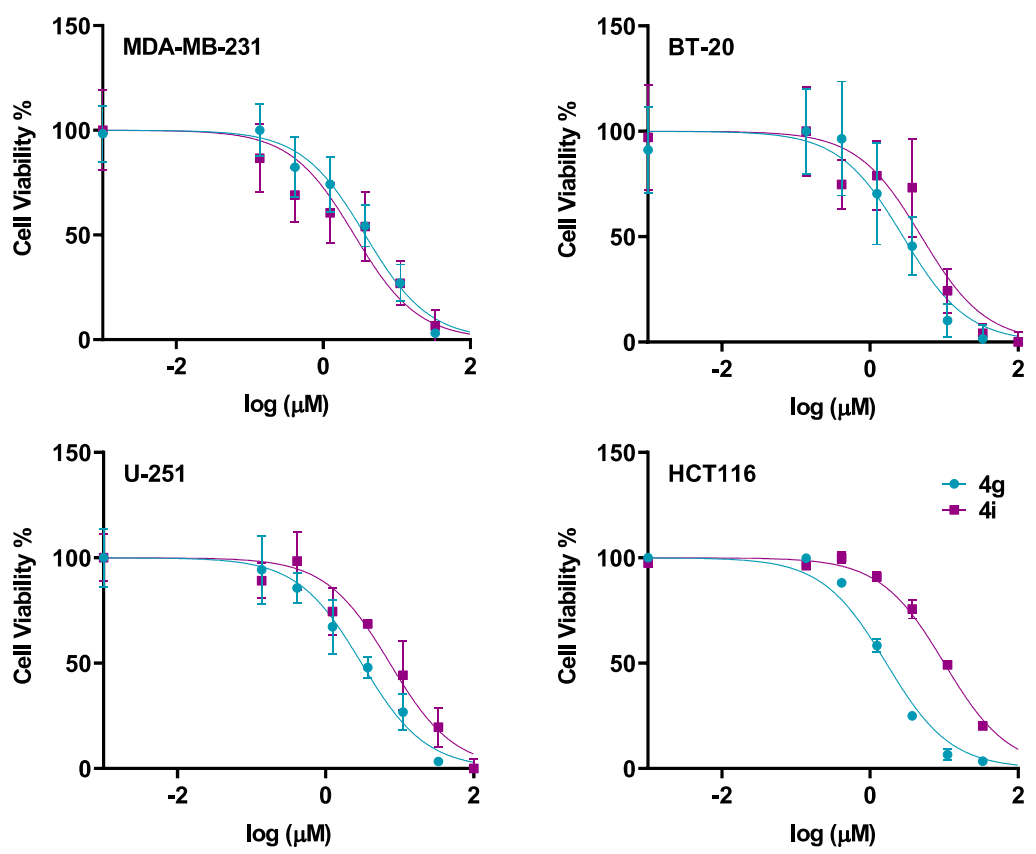

Figure 2. Cont. 
B

$4 g$

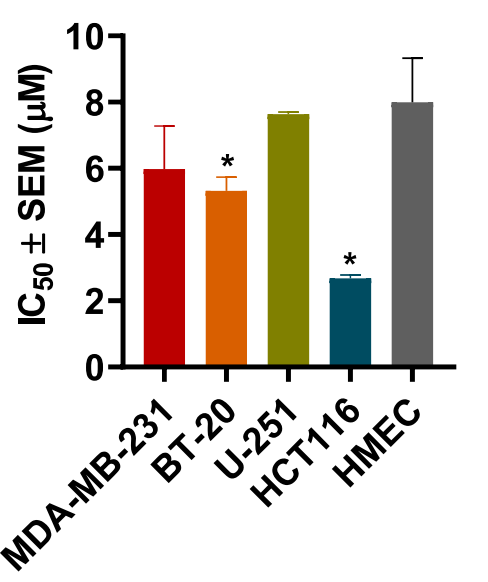

$4 \mathbf{i}$

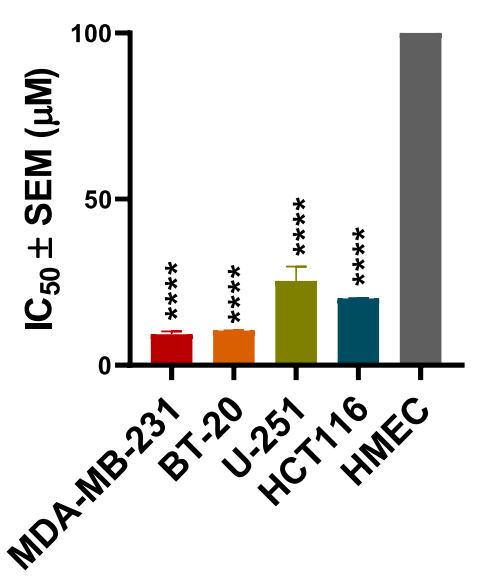

Figure 2. The efficacy and selectivity of $\mathbf{4 g}$ and $4 \mathbf{i}$ in MDA-MB-231, BT-20, U-251, and HCT116, and compared to the normal cell line, $\operatorname{HMEC~(A)~the~viability~curves~for~cancer~cells~(MDA-MB-231,~}$ BT-20, U-251, HCT116), and the normal cell line, HMEC; (B) the $\mathrm{IC}_{50}$ values of $\mathbf{4 g}$ and $4 \mathbf{i}$ for these cell lines are also compared to the normal cell line. Cell survival was determined using the 3-(4,5-dimethylthiazol-2yl)-2,5-diphenyltetrazolium bromide (MTT) assay. The $\mathrm{IC}_{50}$ values are represented as the means $\pm \mathrm{SD}$ of three independent experiments performed in triplicate with * $p<0.05$, **** $p<0.0001$ vs. control group.

Table 3. The effects of the chrysin-like compounds (4a-4o) on the survival of cancer cell lines (breast, glioblastoma, and colon) and a normal non-cancerous cell line (normal human mammary epithelial cells).

\begin{tabular}{ccccc}
\hline Compound & Breast Cancer & Brain Cancer & Colon Cancer & Normal Cells \\
\hline $\mathbf{B T - 2 0}$ & $\mathbf{U - 2 5 1}$ & HCT116 & HMEC \\
\hline $\mathbf{4 a}$ & $4.41 \pm 0.99$ & $8.63 \pm 4.86$ & $2.88 \pm 0.09$ & $7.12 \pm 4.55$ \\
$\mathbf{4}$ & $5.32 \pm 0.72$ & $7.64 \pm 0.11$ & $2.68 \pm 0.15$ & $8.00 \pm 1.33$ \\
$\mathbf{4}$ & $10.43 \pm 0.20$ & $25.36 \pm 7.53$ & $20.09 \pm 0.13$ & $>100$ \\
$\mathbf{4 0}$ & $7.25 \pm 1.82$ & $11.27 \pm 2.84$ & $3.85 \pm 0.34$ & $7.17 \pm 4.10$ \\
\hline
\end{tabular}

Cell survival was determined by MTT assay as described in the materials and methods. The $\mathrm{IC}_{50}$ values $(\mu \mathrm{M})$ are represented as the mean \pm SEM of three independent experiments performed in triplicate. The compounds were screened on breast (MDA-MB-231, BT-20), brain (U-251), and colon (HCT116) cancer cell lines and normal human mammary epithelial cells (HMECs).

\section{3. $4 g$ and $4 i$ Induce Apoptosis and G2 Cell Cycle Arrest in a Triple-Negative Breast Cancer Cell Line}

Apoptosis, a type of programmed cell death, is one of the major mechanisms by which chemotherapeutic drugs produce their therapeutic efficacy [43]. Morphologically, apoptosis is characterized by cellular shrinkage, which is accompanied with nuclear chromatin condensation and fragmentation followed by blebbing of the plasma membrane. This leads to the formation of small apoptotic bodies that have an intact cellular membrane and unaltered organelle integrity. These bodies are then released in the extracellular environment and removed by the process of phagocytosis [44,45]. Apoptosis can occur by two pathways: The extrinsic pathway and intrinsic pathway. In either pathway, when the cell is exposed to certain extrinsic or intrinsic stimuli, the integrity of the inner mitochondrial membrane of the cell is compromised, resulting in the loss of the mitochondrial membrane potential, and causing the release of several apoptotic factors, including cytochrome c [46,47]. Numerous studies indicate that during apoptosis, phosphatidylserine (PS), in the cytoplasmic side of the plasma membrane, is translocated to the extracellular cell surface [48]. The flipped anionic PS binds to the $\mathrm{Ca}^{2+}$-dependent phospholipid-binding protein, annexin V [49]. We discovered and reported several potent apoptosis-inducing compounds [50-57]. In this study, the result of our morphological studies in MDA-MB-231 cells after incubation with our lead compounds, $\mathbf{4 g}$ and $\mathbf{4 i}$, indicated that apoptosis was 
occurring (Figure 3A). At a concentration of $20 \mu \mathrm{M}$, both compounds decreased the number of adherent MDA-MB-231 cells and induced cellular shrinkage. The cells were rounded and loosely attached, and apoptotic bodies were present. Similarly, the incubation of MDA-MB-231 cells with compounds $\mathbf{4 g}$ or $4 \mathbf{i}$ for $24 \mathrm{~h}$ produced a significant loss of the mitochondrial membrane potential. For compound $4 \mathbf{g}$, the population of cells undergoing apoptosis increased from $14.30 \%$ at $0 \mu \mathrm{M}$ to $26.56 \%$ and $58.05 \%$ at 5 and $10 \mu \mathrm{M}$, respectively ( $p$ value $<0.0001$; Figure 3B,C). Compound $4 \mathbf{i}$ also produced a significant shift in the apoptotic cell population in quadrant II, from $14.78 \%$ at $0 \mu \mathrm{M}$ to $32.25 \%$ and $42.56 \%$ at 5 and $10 \mu \mathrm{M}$, respectively ( $p$ value $<0.0001$, Figure 3B,C). Cell cycle analysis indicated that compounds $4 \mathrm{~g}$ and 4i produced a significant disruption in the cell cycle of MDA-MB-231 cells (Figure 3D). Data obtained using flow cytometry indicated that, when incubated with vehicle alone, MDA-MB-231 cells had a normal cell cycle $(5.43 \%, 83.4 \%, 4.63 \%$, and $4.46 \%$ in the subG1, G1, S, and G2 phases, respectively). However, incubation of MDA-MB-231 cells with compound $\mathbf{4 g}$ resulted in a significant shift towards the $\mathrm{G} 2$ phase $(59.12 \%$ and $54.13 \%$ for 5 and $10 \mu \mathrm{M}$, respectively ( $p$ value $<0.0001$, Figure $3 \mathrm{E}$ ).

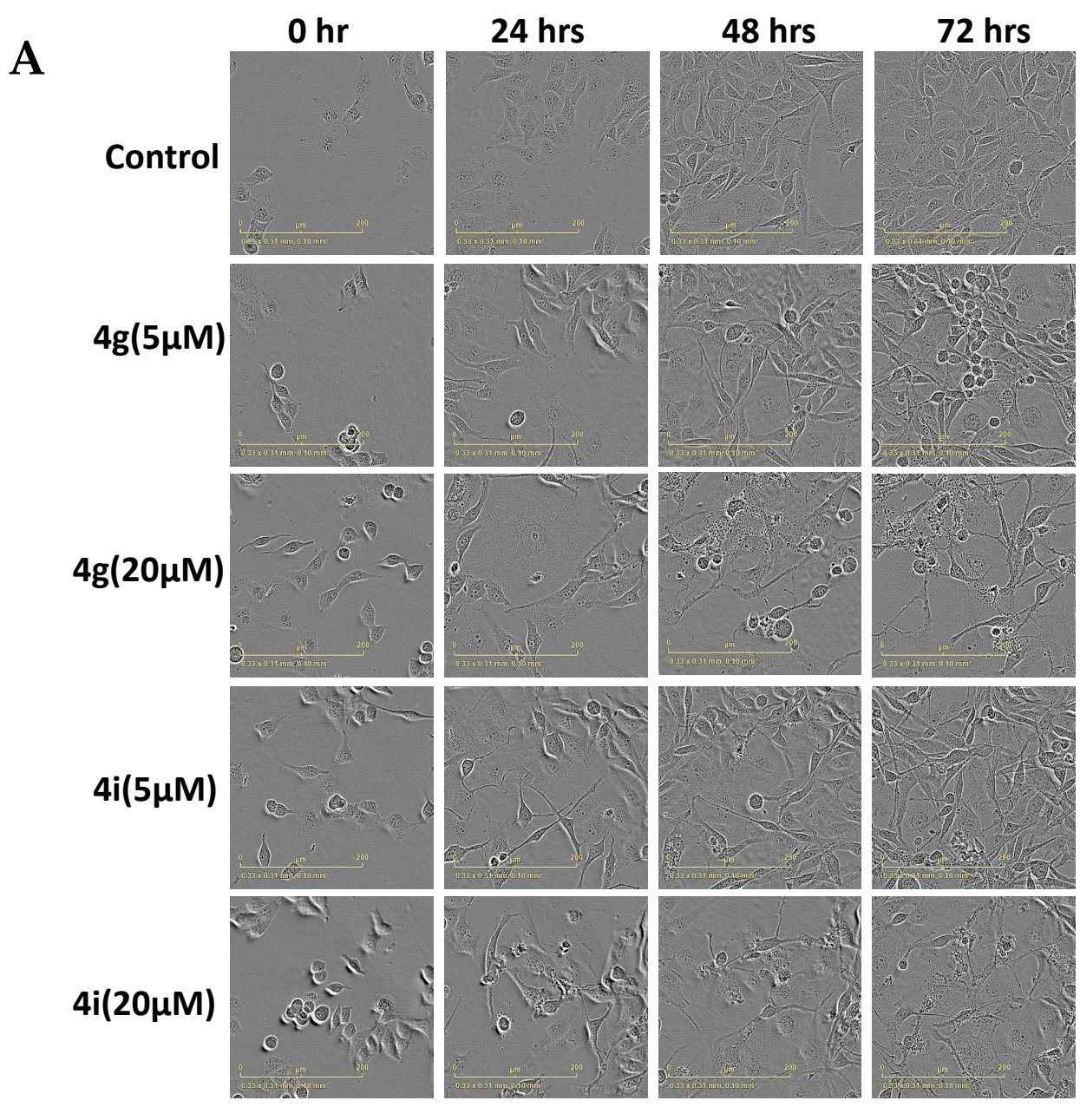

Figure 3. Cont. 
B

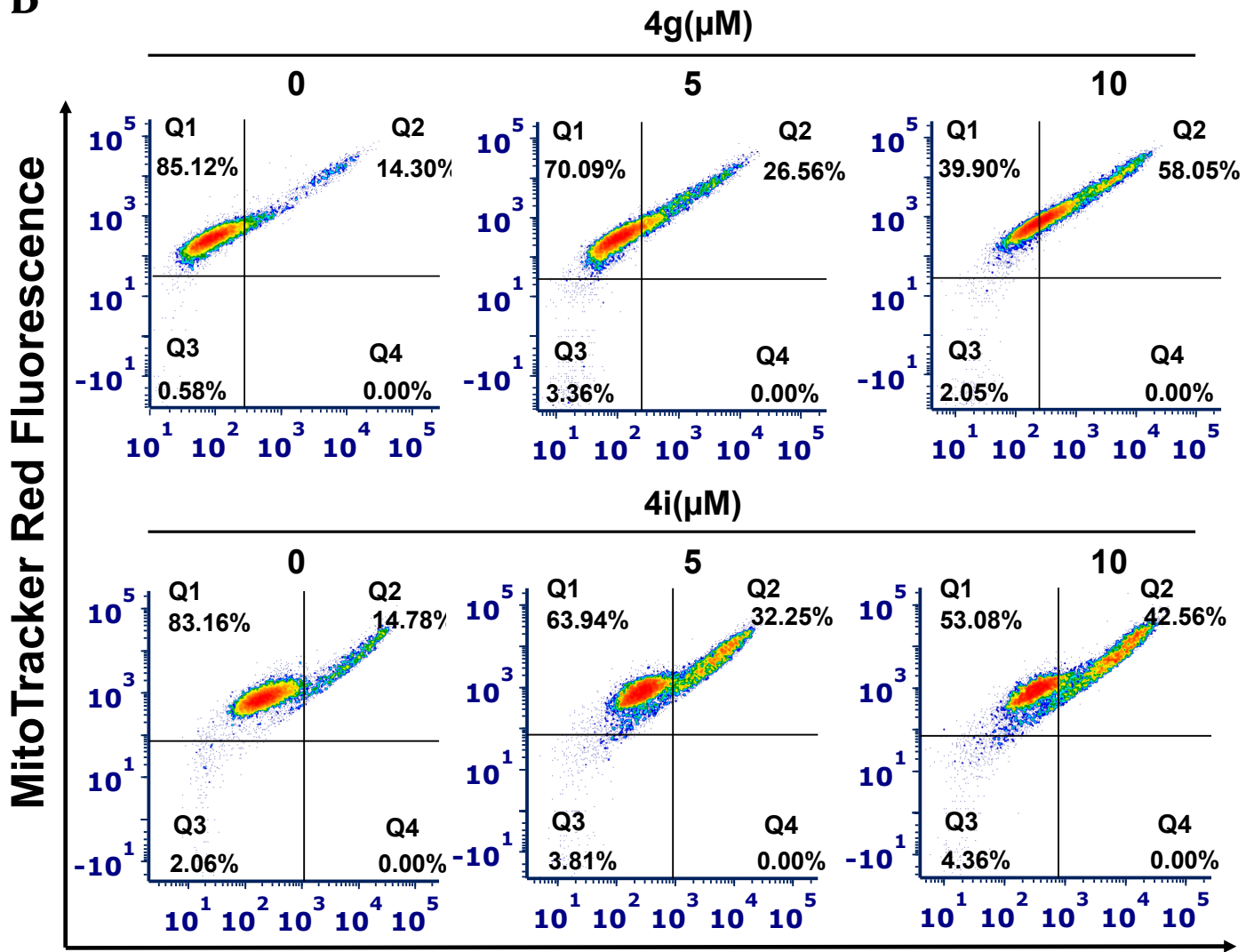

C

Alexa Fluor 488 Dye Fluorescence
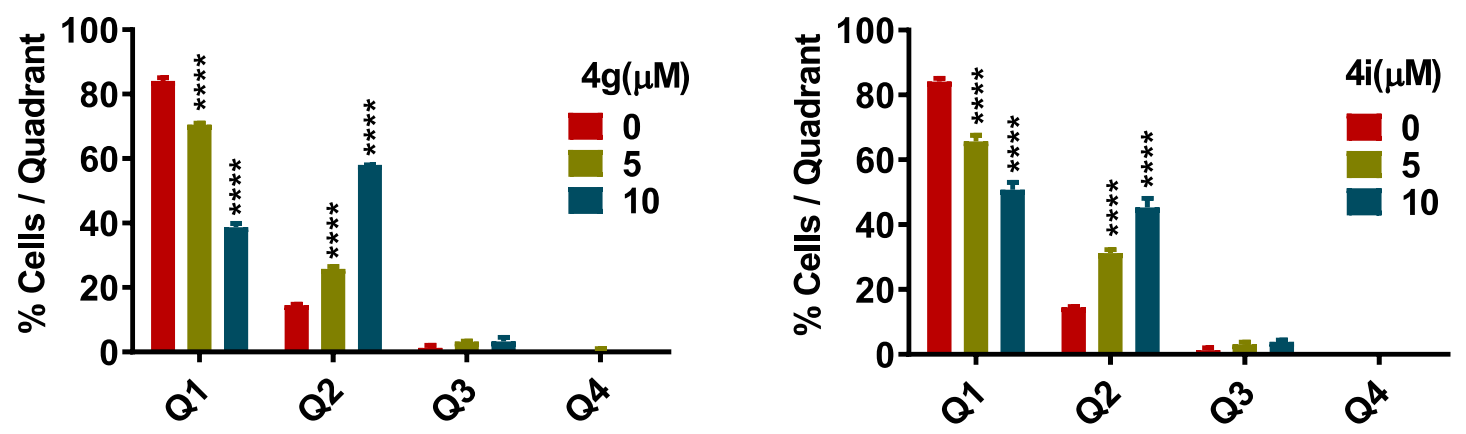

Figure 3. Cont. 
D

$4 \mathrm{~g}(\mu \mathrm{M})$

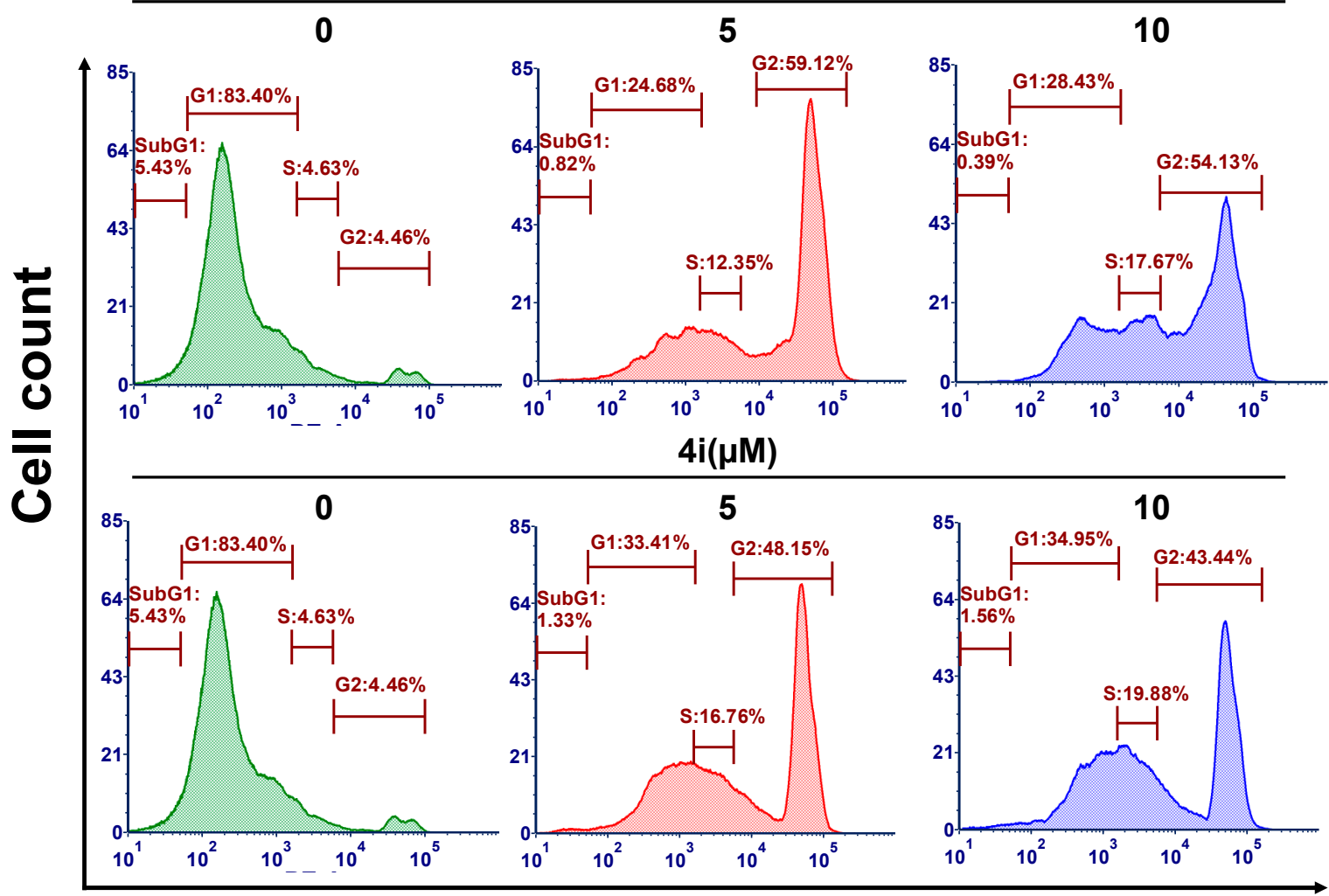

E

FL2-H (PI)
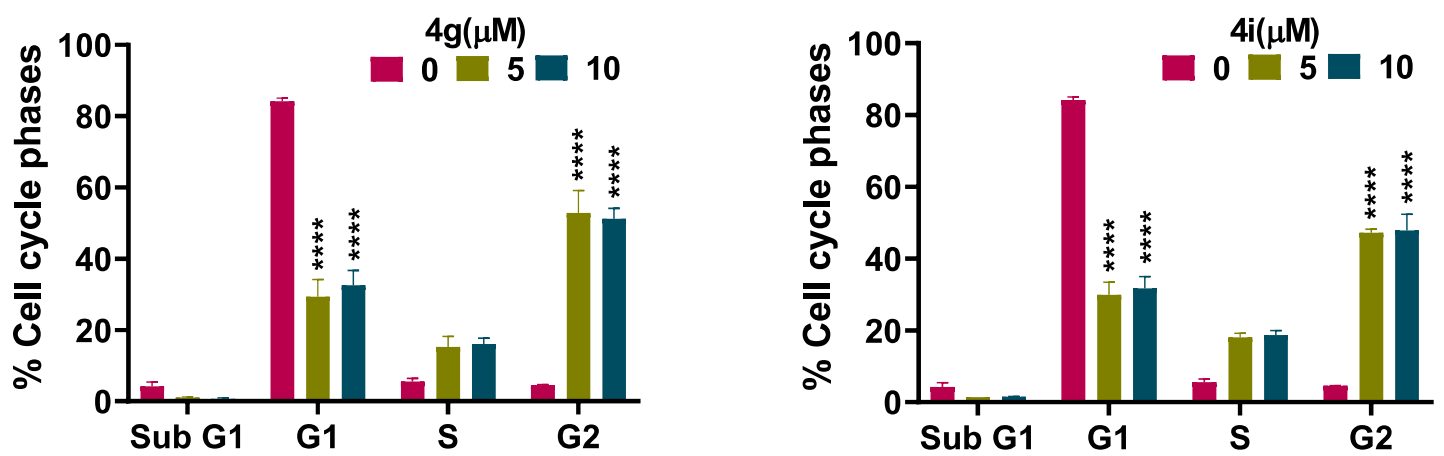

Figure 3. Effects of $4 \mathbf{g}$ and $4 \mathbf{i}$ on cellular morphology, mitochondrial membrane potential, and cell cycle (A) Morphological observations of MDA-MB-231 cells incubated with 0,5 , and $20 \mu \mathrm{M}$ concentrations of $4 \mathrm{~g}$ and $4 \mathbf{i}$ at different time intervals of $0,24,48$, and $72 \mathrm{~h}$, respectively; (B) The MDA-MB-231 cells in complete medium were incubated with $4 \mathrm{~g}$ and $4 \mathbf{i}$ at 0,5 , or $10 \mu \mathrm{M}$ for $24 \mathrm{~h}$. Cells were then incubated with the reagents of the MitoTracker Red and Alexa Fluor 488 annexin V kits for flow cytometry. Representative results of MDA-MB-231 cells from two independent experiments, each performed in triplicate, are shown; (C) Histograms quantitatively summarize the results following incubation with $\mathbf{4 g}$ and $\mathbf{4 i}$, respectively; (D) The induction of cell cycle arrest in MDA-MB-231 cells by $\mathbf{4} \mathbf{g}$ and $\mathbf{4 i}$ is shown. The MDA-MB-231 cells were incubated with different concentrations $(0,5$, and $10 \mu \mathrm{M})$ of $4 \mathrm{~g}$ and $4 \mathbf{i}$ for $24 \mathrm{~h}$ and were subjected to cell cycle analysis by flow cytometry of PI (X axis)/cell counts (Y axis); (E) A histogram quantitatively summarizing the change in $\%$ of cells in each phase of the cell cycle due to incubation with $4 \mathrm{~g}$ and $4 \mathbf{i}$. The data represents means \pm SEM of three independent experiments performed in triplicate with ${ }^{* * * *} p<0.0001$ vs. control group. 


\subsection{Compounds $\mathbf{4 g}$ and $\mathbf{4 i}$ Activate Apoptosis by Activating the Intrinsic Apoptotic Pathway}

Apoptosis can be induced by the activation of two major pathways: The intrinsic and extrinsic apoptotic pathways [22]. The activation of the intrinsic apoptotic pathway induces the activation of proapoptotic proteins, such as apoptosis regulator Bak (Bcl-2 homologous antagonist/killer) and Bax (Bcl-2-associated X protein) [58]. The activated the Bax and Bak proteins subsequently permeabilize the mitochondrial outer membrane by forming pores on its outer surface [58-60]. Consequently, cytochrome c (Cyt C) is released into the cytosol, where it combines with the adaptor protein (Apaf-1) to form an apoptosome [22]. The initiator caspases (i.e., caspase-2, caspase-8, caspase-9, or caspase-10) are activated and recruited to large protein complexes, resulting in the cleavage of the executioner caspases, caspase-3 or caspase-7 [61].

Since MDA-MB-231 cells incubated with compounds $\mathbf{4} \mathbf{g}$ and $\mathbf{4 i}$ had a decrease in the mitochondrial membrane potential, which is an early event of intrinsic apoptosis, i.e., altered permeability of the inner mitochondrial membrane, we conducted experiments to determine if these compounds altered the expression of key apoptotic proteins, including cytochrome c, in MDA-MB-231 cells using Western blotting analysis. Our results indicated that compounds $4 \mathrm{~g}$ at $5 \mu \mathrm{M}$, and compound $4 \mathbf{i}$ at $10 \mu \mathrm{M}$ produced a significant increase in the expression of cytochrome c, compared to cells incubated with vehicle (Figure 4A,B). This may be due to an increase in the expression of Bak following incubation with $4 \mathrm{~g}$ and $4 \mathbf{i}$ (Figure $4 \mathrm{~A}, \mathrm{~B}$ ), compared to cells incubated in the absence of lead compounds. In addition, both compounds $(4 \mathrm{~g}$ at $5 \mu \mathrm{M}$ and $4 \mathbf{i}$ at $10 \mu \mathrm{M})$ produced significant cleavage of the initiator caspase, caspase 9, in MDA-MB-231 cells, compared to cells incubated with vehicle (Figure 4A,B). These events activated caspase 7 in breast cancer cells incubated with both concentrations of $4 \mathbf{g}$ and $10 \mu \mathrm{M}$ of $4 \mathbf{i}$, compared to cells incubated with vehicle (Figure 4A,B). In contrast, there was no significant change in the mammalian target of rapamycin (mTOR) expression, indicating that cell death induced by $\mathbf{4 g}$ and $4 \mathbf{i}$ in MDA-MB-231 cells is not due to autophagy (Figure 4A,B). Thus, our results suggest that cytochrome c release induces intracellular initiator caspase activation, followed by the activation of executioner caspases, thus activating apoptotic cell death machinery through intrinsic the pathway.

A

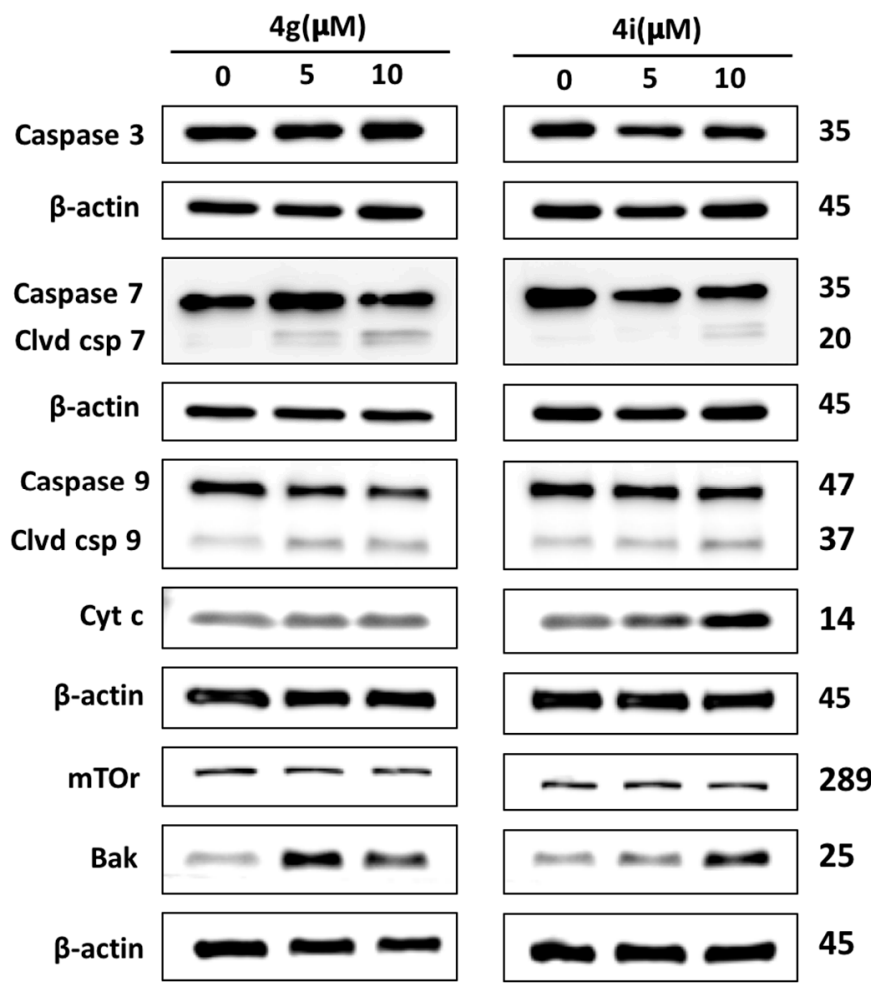

Figure 4. Cont. 

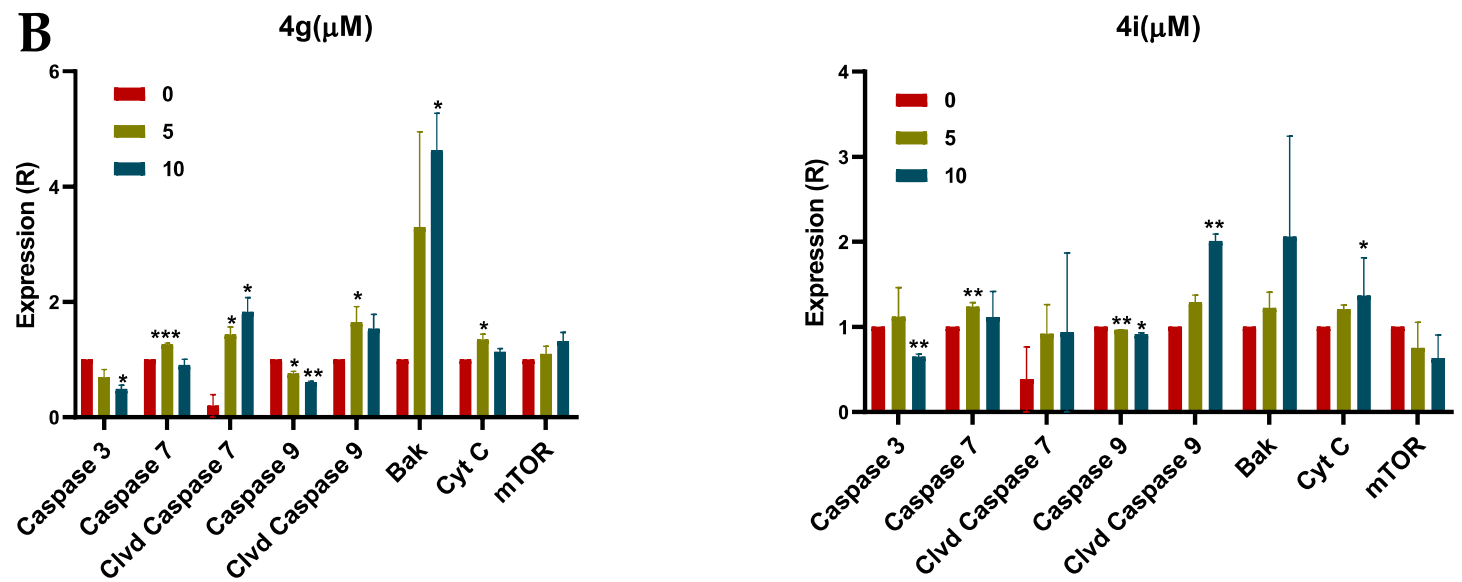

Figure 4. The effect on apoptosis induction at different concentrations of $\mathbf{4 g}$ and $4 \mathbf{i}$ in MDA-MB-231 cells. (A) Western blots for the proteins caspase 3, caspase 7, cleaved caspase 7, caspase 9, cleaved caspase 9, Bak, cyt $\mathrm{C}$ and mTOR following incubation with $\mathbf{4 g}$ and $4 \mathbf{i}$ at 0,5 , or $10 \mu \mathrm{M}$. The values of the proteins were normalized to $\beta$-actin levels. (B) Histograms summarizing the levels of each protein are also shown. All the data are presented as the means \pm SEM of three independent studies with * $p<0.05$, ${ }^{* *} p<0.01,{ }^{* * *} p<0.001$ vs. control group. Cleaved is abbreviated as Clvd.

\section{Materials and Method}

\subsection{Chemistry}

All chemicals and solvents were procured from commercial sources (reagent grade) and were used without further purification. The reaction progress was monitored by thin layer chromatography (TLC) using precoated TLC plates of silica gel $60 \mathrm{~F} 254 .{ }^{1} \mathrm{H}-\mathrm{NMR}$ and ${ }^{13} \mathrm{C}-\mathrm{NMR}$ spectra were recorded using a $400 \mathrm{MHz}$ Bruker Avance Ultrashield spectrometer. The spectra were obtained in ppm using automatic calibration to the residual proton peak of the solvent, dimethyl-sulphoxide (DMSO- $\mathrm{d}_{6}$ ). The ${ }^{1} \mathrm{H}$ NMR data are presented as follows: Chemical shift $(\delta \mathrm{ppm})$, multiplicity $(\mathrm{s}=$ singlet, $\mathrm{d}=$ doublet, $\mathrm{t}=$ triplet, $\mathrm{q}=$ quartet, $\mathrm{m}=$ multiplet), coupling constants $(\mathrm{Hz})$, and integration. The ${ }^{13} \mathrm{C}$ NMR analyses were reported in terms of the chemical shift. The ${ }^{1} \mathrm{H}$ and ${ }^{13} \mathrm{C}$ NMR spectra for all compounds are included in the supporting information (Figure S1). HRMS data were acquired using a Thermo QExactive Plus mass spectrometer equipped with an electrospray ionization source (Thermo Fisher Scientific, Greensboro, NC, USA).

\subsubsection{Synthesis of methyl 2-((5-Hydroxy-4-oxo-2-phenyl-4H-chromen-7-yl)oxy)acetate (2)}

The title compound was synthesized as previously described [62].

\subsubsection{Synthesis of 2-((5-Hydroxy-4-oxo-2-phenyl-4H-chromen-7-yl)oxy)acetohydrazide (3)}

The title compound was synthesized according to our previously published procedure [29].

3.1.3. General Procedure for the Synthesis of $N^{\prime}$-arylidene-2-((5-Hydroxy-4-oxo-2-phenyl-4H-chromen7-yl)oxy)acetohydrazide (4a-4o)

To a stirred suspension of hydrazide $3(1.0 \mathrm{~g}$, $3.0 \mathrm{mmol})$ in anhydrous methanol $(60 \mathrm{~mL})$, the appropriate aldehyde $(3.0 \mathrm{mmol})$ was added, along with a few drops of concentrated hydrochloric acid. After one hour, the reaction was completed and the formed precipitate was separated by filtration, washed with methanol, and dried in air to give pure compounds in good yields. 
(E,Z)-2-((5-Hydroxy-4-oxo-2-phenyl-4H-chromen-7-yl)oxy)-N'-(2-hydroxybenzylidene)acetohydrazide (4a)

The product was obtained as a pale-yellow powder. Yield (64\%). ${ }^{1} \mathrm{H}$ NMR (DMSO- $\left.d_{6}\right)(E: Z=1: 1)$ : $\delta 12.84-12.81(\mathrm{~m}, 2 \mathrm{H}), 11.84(\mathrm{~s}, 1 \mathrm{H}), 11.62(\mathrm{~s}, 1 \mathrm{H}), 10.99(\mathrm{~s}, 1 \mathrm{H}), 10.05(\mathrm{~s}, 1 \mathrm{H}), 8.57(\mathrm{~s}, 1 \mathrm{H}), 8.33(\mathrm{~s}, 1 \mathrm{H})$, $8.12-8.10(\mathrm{~d}, J=8 \mathrm{~Hz}, 4 \mathrm{H}), 7.77-7.55(\mathrm{~m}, 8 \mathrm{H}), 7.31-7.24(\mathrm{~m}, 2 \mathrm{H}), 7.07-6.85(\mathrm{~m}, 8 \mathrm{H}), 6.51-6.42(\mathrm{~m}, 2 \mathrm{H})$, $5.31(\mathrm{~s}, 2 \mathrm{H}), 4.87(\mathrm{~s}, 2 \mathrm{H}) .{ }^{13} \mathrm{C}$ NMR (DMSO- $\left.d_{6}\right): \delta 182.11,182.06,167.94,164.42,163.65,163.61,163.48$, 163.37, 161.17, 161.07, 157.36, 157.22, 156.45, 148.27, 141.63, 132.18, 132.12, 131.59, 131.29, 130.57, 130.54, $129.18,129.15,129.11,126.56,126.47,120.01,119.40,118.65,116.39,116.14,105.44,105.39,105.31,105.09$, 98.81, 98.72, 93.62, 93.46, 66.57, 65.36. HRMS (ESI, $m / z$ ): calculated for $\mathrm{C}_{24} \mathrm{H}_{19} \mathrm{~N}_{2} \mathrm{O}_{6}[\mathrm{M}+\mathrm{H}]^{+} 431.1237$; found 431.1238 .

(E,Z)-N'-Benzylidene-2-((5-hydroxy-4-oxo-2-phenyl-4H-chromen-7-yl)oxy)acetohydrazide (4b)

The synthesis and full characterization of the title compound have been previously reported [29].

(E,Z)-2-((5-Hydroxy-4-oxo-2-phenyl-4H-chromen-7-yl)oxy)-N'-(2-methoxybenzylidene)acetohydrazide (4c)

The product was obtained as a yellow powder. Yield (55\%). ${ }^{1} \mathrm{H}$ NMR (DMSO- $\left.d_{6}\right)(E: Z=1: 0.5)$ : $\delta 12.84-12.80(\mathrm{~m}, 1.5 \mathrm{H}), 11.64(\mathrm{~s}, 1.5 \mathrm{H}), 8.68(\mathrm{~s}, 0.5 \mathrm{H}), 8.37(\mathrm{~s}, 1 \mathrm{H}), 8.11-8.09(\mathrm{~d}, J=8 \mathrm{~Hz}, 3 \mathrm{H}), 7.91-7.89$ $(\mathrm{d}, J=8 \mathrm{~Hz}, 1 \mathrm{H}), 7.82-7.80(\mathrm{~d}, J=8 \mathrm{~Hz}, 0.5 \mathrm{H}), 7.63-7.55(\mathrm{~m}, 4.5 \mathrm{H}), 7.44-7.4(\mathrm{~m}, 1.5 \mathrm{H}), 7.12-7.0(\mathrm{~m}, 4.5 \mathrm{H})$, 6.88-6.84 (m, 1.5H), 6.5-6.42 (m, 1.5H), $5.32(\mathrm{~s}, 2 \mathrm{H}), 4.82(\mathrm{~s}, 1 \mathrm{H}), 3.86(\mathrm{~s}, 4.5 \mathrm{H}) .{ }^{13} \mathrm{C}$ NMR (DMSO- $\left.d_{6}\right)$ : 8182.09, 182.03, 168.09, 164.43, 163.71, 163.60, 163.48, 163.22, 161.13, 161.05, 157.80, 157.64, 157.21, $143.56,139.73,132.15,132.10,131.72,131.48,130.55,129.09,126.45,125.67,125.53,121.94,120.72,120.66$, 111.84, 111.77, 105.42, 105.31, 105.06, 98.77, 98.70, 93.62, 93.45, 66.65, 65.36, 55.68, 54.87. HRMS (ESI, $m / z$ ): calculated for $\mathrm{C}_{25} \mathrm{H}_{21} \mathrm{~N}_{2} \mathrm{O}_{6}[\mathrm{M}+\mathrm{H}]^{+}$445.1394; found 445.1392 .

(E,Z)-N'-(2-Ethoxybenzylidene)-2-((5-hydroxy-4-oxo-2-phenyl-4H-chromen-7-yl)oxy)acetohydrazide (4d)

The product was obtained as a light-brown powder. Yield $(80 \%) .{ }^{1} \mathrm{H} N M R\left(D M S O-d_{6}\right)(E: Z=1: 0.5)$ : $\delta 12.84-12.80(\mathrm{~m}, 1.5 \mathrm{H}), 11.68-11.62(\mathrm{~m}, 1.5 \mathrm{H}), 8.66(\mathrm{~s}, 0.5 \mathrm{H}), 8.40(\mathrm{~s}, 1 \mathrm{H}), 8.11-8.10(\mathrm{~d}, J=4 \mathrm{~Hz}, 3 \mathrm{H})$, 7.90-7.80 (m, 1.5H), 7.60-7.57 (m, 4.5H), 7.41-7.37 (m, 1.5H), 7.10-6.84 (m, 6H), 6.5-6.42 (m, 1.5H), 5.31 $(\mathrm{s}, 2 \mathrm{H}), 4.82(\mathrm{~s}, 1 \mathrm{H}), 4.14-4.09(\mathrm{q}, J=8 \mathrm{~Hz}, 3 \mathrm{H}), 1.39-1.35(\mathrm{t}, J=8 \mathrm{~Hz}, 4.5 \mathrm{H}) \cdot{ }^{13} \mathrm{C}$ NMR (DMSO- $\left.d_{6}\right):$ $\delta 182.08,182.03,168.03,164.42,163.77,163.57,163.46,163.23,161.14,161.04,157.20,157.13,156.98$, 143.46, 140.01, 132.10, 131.67, 131.42, 130.54, 129.09, 126.45, 125.76, 125.58, 122.14, 122.09, 120.61, 112.75, $105.41,105.29,105.05,98.71,93.63,93.45,66.62,65.36,63.80,14.63$. HRMS (ESI, $m / z)$ : calculated for $\mathrm{C}_{26} \mathrm{H}_{23} \mathrm{~N}_{2} \mathrm{O}_{6}[\mathrm{M}+\mathrm{H}]^{+}$459.1550; found 459.1548.

(E,Z)-2-((5-Hydroxy-4-oxo-2-phenyl-4H-chromen-7-yl)oxy)- $N^{\prime}$-(4-hydroxybenzylidene)acetohydrazide (3e)

The synthesis and full characterization of the title compound were previously published [29].

(E,Z)-2-((5-Hydroxy-4-oxo-2-phenyl-4H-chromen-7-yl)oxy)-N'-(4-methoxybenzylidene)acetohydrazide (3f)

The synthesis and full characterization of the title compound were previously published [29].

(E,Z)-N'-(2,4-Dihydroxybenzylidene)-2-((5-hydroxy-4-oxo-2-phenyl-4H-chromen-7yl)oxy)acetohydrazide (4g)

The product was obtained as an off-white powder. Yield (85\%). ${ }^{1} \mathrm{H}$ NMR (DMSO- $\left.\mathrm{d}_{6}\right)(E: Z=1: 0.8)$ : $\delta 12.84-12.80(\mathrm{~m}, 1.8 \mathrm{H}), 11.67(\mathrm{~s}, 1 \mathrm{H}), 11.43(\mathrm{~s}, 0.8 \mathrm{H}), 11.15(\mathrm{~s}, 1 \mathrm{H}), 9.98(\mathrm{~s}, 1.8 \mathrm{H}), 9.83(\mathrm{~s}, 0.8 \mathrm{H}), 8.42$ $(\mathrm{s}, 1 \mathrm{H}), 8.20(\mathrm{~s}, 0.8 \mathrm{H}), 8.12-8.10(\mathrm{~d}, J=8 \mathrm{~Hz}, 3.6 \mathrm{H}), 7.63-7.53(\mathrm{~m}, 6.2 \mathrm{H}), 7.33-7.31(\mathrm{~d}, J=8 \mathrm{~Hz}, 1 \mathrm{H})$, $7.08-7.06(\mathrm{~d}, J=8 \mathrm{~Hz}, 1.8 \mathrm{H}), 6.89(\mathrm{~d}, J=2 \mathrm{~Hz}, 1 \mathrm{H}), 6.8(\mathrm{~d}, J=2.4 \mathrm{~Hz}, 0.8 \mathrm{H}), 6.5(\mathrm{~d}, J=2 \mathrm{~Hz}, 1 \mathrm{H}), 6.4(\mathrm{~d}$, $J=2 \mathrm{~Hz}, 0.8 \mathrm{H}), 6.36-6.30(\mathrm{~m}, 3.6 \mathrm{H}), 5.26(\mathrm{~s}, 1.6 \mathrm{H}), 4.83(\mathrm{~s}, 2 \mathrm{H}) .{ }^{13} \mathrm{C}$ NMR (DMSO- $\left.d_{6}\right): \delta 182.10,182.05$, $167.42,164.44,163.68,163.64,163.50,162.86,161.14,161.04,160.86,160.53,159.35,158.07,157.23,149.28$, $142.68,132.18,132.12,131.10,130.55,129.15,129.12,128.27,126.47,111.49,110.37,107.84,107.77,105.45$, 
105.37, 105.32, 105.07, 102.60, 102.37, 98.81, 98.72, 93.63, 93.45, 66.59, 65.33. HRMS (ESI, $m / z)$ : calculated for $\mathrm{C}_{24} \mathrm{H}_{19} \mathrm{~N}_{2} \mathrm{O}_{7}[\mathrm{M}+\mathrm{H}]^{+}$447.1186; found 447.1187.

(E,Z)-N'-(2,4-Dimethoxybenzylidene)-2-((5-hydroxy-4-oxo-2-phenyl-4H-chromen-7-

yl)oxy)acetohydrazide (4h)

The product was obtained as a yellow powder. Yield $(96 \%) .{ }^{1} \mathrm{H}$ NMR (DMSO- $\left.d_{6}\right)(E: Z=1: 0.5)$ : $\delta 12.81(\mathrm{~s}, 1.5 \mathrm{H}), 11.49(\mathrm{~s}, 1.5 \mathrm{H}), 8.58(\mathrm{~s}, 0.5 \mathrm{H}), 8.27(\mathrm{~s}, 1 \mathrm{H}), 8.11-8.10(\mathrm{~m}, 3 \mathrm{H}), 7.84-7.57(\mathrm{~m}, 6 \mathrm{H}), 7.05(\mathrm{~s}$, $1.5 \mathrm{H}), 6.88-6.84(\mathrm{~m}, 1.5 \mathrm{H}), 6.63-6.41(\mathrm{~m}, 4.5 \mathrm{H}), 5.29(\mathrm{~s}, 2 \mathrm{H}), 4.79(\mathrm{~s}, 1 \mathrm{H}), 3.86-3.82(\mathrm{~m}, 9 \mathrm{H}) .{ }^{13} \mathrm{C}$ NMR (DMSO- $d_{6}$ ): $\delta 182.04,167.79,164.43,163.69,163.55,163.44,162.91,162.55,162.33,161.09,161.02,159.19$, $159.02,157.18,143.62,139.82,132.10,130.53,129.09,126.78,126.43,114.76,106.41,105.38,105.28,105.02$, 98.68, 98.24, 98.07, 93.59, 93.42, 66.66, 65.35, 55.74, 55.40.HRMS (ESI, $m / z$ ): calculated for $\mathrm{C}_{26} \mathrm{H}_{23} \mathrm{~N}_{2} \mathrm{O}_{7}$ $[\mathrm{M}+\mathrm{H}]^{+}$475.1499; found 475.1499.

(E,Z)-2-((5-Hydroxy-4-oxo-2-phenyl-4H-chromen-7-yl)oxy)- $N^{\prime}-(2,3,4-$ trihydroxybenzylidene)acetohydrazide (4i)

The product was obtained as a yellow powder. Yield $(85 \%) .{ }^{1} \mathrm{H}$ NMR (DMSO- $\left.d_{6}\right)(E: Z=1: 0.5)$ : $\delta 12.84-12.80(\mathrm{~m}, 1.5 \mathrm{H}), 11.71(\mathrm{~s}, 1 \mathrm{H}), 11.47(\mathrm{~s}, 0.5 \mathrm{H}), 11.18(\mathrm{~s}, 1 \mathrm{H}), 9.57-9.51(\mathrm{~m}, 1.5 \mathrm{H}), 9.37(\mathrm{~s}, 0.5 \mathrm{H})$, 8.54-8.50 (m, 1.5H), $8.38(\mathrm{~s}, 1 \mathrm{H}), 8.18-8.10(\mathrm{~m}, 3.5 \mathrm{H}), 7.61-7.59(\mathrm{~m}, 4.5 \mathrm{H}), 7.07-7.0(\mathrm{~m}, 2 \mathrm{H}), 6.90-6.78(\mathrm{~m}$, 2.5H), 6.51-6.38 (m, 3H), $5.26(\mathrm{~s}, 1 \mathrm{H}), 4.85(\mathrm{~s}, 2 \mathrm{H}) .{ }^{13} \mathrm{C} \mathrm{NMR}$ (DMSO- $\left.d_{6}\right): \delta 182.12,182.07,167.34,164.42$, 163.68, 163.54, 162.93, 161.16, 161.07, 157.25, 150.45, 148.91, 148.42, 147.47, 146.65, 144.18, 132.76, 132.71, 132.21, 132.16, 130.56, 129.18, 126.49, 121.11, 118.36, 112.11, 110.70, 107.84, 107.73, 105.46, 105.40, 105.34, 105.10, 98.83, 98.75, 93.65, 93.48, 66.59, 65.32. HRMS (ESI, $m / z$ ): calculated for $\mathrm{C}_{24} \mathrm{H}_{19} \mathrm{~N}_{2} \mathrm{O}_{8}[\mathrm{M}+\mathrm{H}]^{+}$ 463.1134; found 463.1133.

(E,Z)-2-((5-Hydroxy-4-oxo-2-phenyl-4H-chromen-7-yl)oxy)-N'-(2,4,6trihydroxybenzylidene)acetohydrazide (4j)

The product was obtained as a brown powder. Yield $(76 \%) .{ }^{1} \mathrm{H}$ NMR (DMSO- $\left.d_{6}\right)(E: Z=1: 0.2)$ : $\delta 12.83-12.79(\mathrm{~m}, 1.2 \mathrm{H}), 11.65(\mathrm{~s}, 1 \mathrm{H}), 11.48(\mathrm{~s}, 0.2 \mathrm{H}), 10.99(\mathrm{~s}, 2 \mathrm{H}), 10.32(\mathrm{~s}, 0.4 \mathrm{H}), 9.85(\mathrm{~s}, 1.2 \mathrm{H}), 8.72(\mathrm{~s}$, $1 \mathrm{H}), 8.41(\mathrm{~s}, 0.2 \mathrm{H}), 8.09-8.08(\mathrm{~m}, 2.4 \mathrm{H}), 7.59-7.58(\mathrm{~m}, 3.6 \mathrm{H}), 7.04(\mathrm{~m}, 1.2 \mathrm{H}), 6.88-6.84(\mathrm{~m}, 1.2 \mathrm{H}), 6.5-6.42$ $(\mathrm{m}, 1.2 \mathrm{H}), 5.86-5.83(\mathrm{~m}, 2.4 \mathrm{H}), 5.2(\mathrm{~s}, 0.4 \mathrm{H}), 4.82(\mathrm{~s}, 2 \mathrm{H}) .{ }^{13} \mathrm{C}$ NMR $\left(\mathrm{DMSO}_{6}\right): \delta 182.08,166.56,164.28$, 163.61, 163.51, 162.55, 161.74, 161.46, 161.12, 161.04, 159.73, 159.24, 157.20, 147.32, 144.33, 132.15, 130.54, 129.13, 126.45, 105.43, 105.37, 105.11, 98.85, 98.79, 94.37, 93.61, 93.50, 66.58, 65.26. HRMS (ESI, $m / z)$ : calculated for $\mathrm{C}_{24} \mathrm{H}_{19} \mathrm{~N}_{2} \mathrm{O}_{8}[\mathrm{M}+\mathrm{H}]^{+}$463.1134; found 463.1134.

(E,Z)-N'-(Furan-2-ylmethylene)-2-((5-hydroxy-4-oxo-2-phenyl-4H-chromen-7-yl)oxy)acetohydrazide(4k)

The product was obtained as a yellow powder. Yield $(87 \%) .{ }^{1} \mathrm{H}$ NMR (DMSO- $\left.d_{6}\right)(E: Z=1: 0.5)$ : $\delta 12.83-12.79(\mathrm{~m}, 1.5 \mathrm{H}), 11.63-11.57(\mathrm{~m}, 1.5 \mathrm{H}), 8.23(\mathrm{~s}, 0.5 \mathrm{H}), 8.11-8.09(\mathrm{~d}, J=8 \mathrm{~Hz}, 3 \mathrm{H}), 7.92(\mathrm{~s}, 1 \mathrm{H})$, $7.85(\mathrm{~s}, 1.5 \mathrm{H}), 7.63-7.55(\mathrm{~m}, 4.5 \mathrm{H}), 7.06-7.05(\mathrm{~m}, 1.5 \mathrm{H}), 6.95-6.83(\mathrm{~m}, 3 \mathrm{H}), 6.64(\mathrm{~m}, 1.5 \mathrm{H}), 6.49-6.39(\mathrm{~m}$, $1.5 \mathrm{H}), 5.24(\mathrm{~s}, 2 \mathrm{H}), 4.83(\mathrm{~s}, 1 \mathrm{H}) .{ }^{13} \mathrm{C}$ NMR $\left(\mathrm{DMSO}^{\mathrm{d}} \mathrm{d}\right): \delta 182.03,167.97,164.34,163.66,163.59,163.46$, 163.35, 161.13, 161.02, 157.21, 149.12, 148.94, 145.34, 145.10, 137.86, 134.20, 132.11, 130.54, 129.09, 126.45, 113.95, 113.78, 112.16, 105.42, 105.29, 105.08, 98.70, 93.60, 93.38, 66.65, 65.14.HRMS (ESI, $m / z)$ : calculated for $\mathrm{C}_{22} \mathrm{H}_{17} \mathrm{~N}_{2} \mathrm{O}_{6}[\mathrm{M}+\mathrm{H}]^{+} 405.1081$; found 405.1077 .

(E,Z)-2-((5-Hydroxy-4-oxo-2-phenyl-4H-chromen-7-yl)oxy)-N'-(pyridin-3-ylmethylene)acetohydrazide (41)

The product was obtained as a yellow powder. Yield (86\%). ${ }^{1} \mathrm{H}$ NMR $\left(D M S O-\mathrm{d}_{6}\right)(E: Z=1: 0.5)$ : $\delta 12.82(\mathrm{bs}, 1.5 \mathrm{H}), 11.98(\mathrm{bs}, 1.5 \mathrm{H}), 8.43(\mathrm{~s}, 0.5 \mathrm{H}), 8.30-8.28(\mathrm{~d}, J=8 \mathrm{~Hz}, 3 \mathrm{H}), 8.13-7.96(\mathrm{~m}, 7 \mathrm{H}), 7.62-7.55$ $(\mathrm{m}, 4.5 \mathrm{H}), 7.07-7.06(\mathrm{~m}, 1.5 \mathrm{H}), 6.88(\mathrm{~s}, 1.5 \mathrm{H}), 6.5-6.45(\mathrm{~m}, 1.5 \mathrm{H}), 5.39(\mathrm{~s}, 2 \mathrm{H}), 4.9(\mathrm{~s}, 1 \mathrm{H}) .{ }^{13} \mathrm{C}$ NMR (DMSO-d ${ }_{6}$ ): $\delta 182.12,168.50,164.42,163.67,163.55,161.08,157.27,150.51,148.52,145.40,141.22,133.75$, 132.20, 130.59, 129.96, 129.16, 126.51, 123.94, 105.36, 105.12, 98.76, 93.55, 66.61, 65.40. HRMS (ESI, $m / z)$ : calculated for $\mathrm{C}_{23} \mathrm{H}_{18} \mathrm{~N}_{3} \mathrm{O}_{5}[\mathrm{M}+\mathrm{H}]^{+} 416.1241$; found 416.1240 . 
(E,Z)-2-((5-Hydroxy-4-oxo-2-phenyl-4H-chromen-7-yl)oxy)- $N^{\prime}$-(pyridin-2ylmethylene)acetohydrazide $(4 \mathrm{~m})$

The product was obtained as a brown powder. Yield (52\%). ${ }^{1} \mathrm{H}$ NMR (DMSO- $\left.d_{6}\right)(E: Z=1: 0.5)$ : $\delta 12.84-12.81(\mathrm{~m}, 1.5 \mathrm{H}), 11.89-11.87(\mathrm{~m}, 1.5 \mathrm{H}), 8.61(\mathrm{~m}, 1.5 \mathrm{H}), 8.35(\mathrm{~s}, 0.5 \mathrm{H}), 8.11-8.03(\mathrm{~m}, 5 \mathrm{H}), 7.94-7.87$ $(\mathrm{m}, 2 \mathrm{H}), 7.62-7.55(\mathrm{~m}, 4.5 \mathrm{H}), 7.44-7.41(\mathrm{~m}, 1.5 \mathrm{H}), 7.07-7.06(\mathrm{~m}, 1.5 \mathrm{H}), 6.88(\mathrm{~m}, 1.5 \mathrm{H}), 6.51-6.45(\mathrm{~m}, 1.5 \mathrm{H})$, 5.37 (s, 2H), 4.88 (s, $1 \mathrm{H}) .{ }^{13} \mathrm{C}$ NMR (DMSO- $\left.d_{6}\right): \delta 182.02,168.45,164.34,163.75,163.65,163.59,163.48$, 161.13, 161.05, 157.21, 152.93, 152.78, 149.51, 149.44, 148.26, 144.45, 136.86, 136.75, 132.09, 130.53, 129.07, $126.44,124.52,124.34,119.98,119.90,105.42,105.30,105.09,98.70,93.63,93.48,66.61,65.30$. HRMS (ESI, $m / z)$ : calculated for $\mathrm{C}_{23} \mathrm{H}_{18} \mathrm{~N}_{3} \mathrm{O}_{5}[\mathrm{M}+\mathrm{H}]^{+} 416.1241$; found 416.1238.

(E,Z)-2-((5-Hydroxy-4-oxo-2-phenyl-4H-chromen-7-yl)oxy)-N'-((2-hydroxynaphthalen-1yl)methylene)acetohydrazide (4n)

The product was obtained as a yellow powder. Yield (54\%). ${ }^{1} \mathrm{H}$ NMR (DMSO- $\left.d_{6}\right)(E: Z=1: 0.5)$ : $\delta 12.86-12.81(\mathrm{~m}, 1.5 \mathrm{H}), 12.46(\mathrm{~s}, 1 \mathrm{H}), 11.91(\mathrm{~s}, 1 \mathrm{H}), 11.68(\mathrm{~s}, 0.5 \mathrm{H}), 10.77(\mathrm{~s}, 0.5 \mathrm{H}), 9.40(\mathrm{~s}, 1 \mathrm{H}), 8.89(\mathrm{~s}$, $0.5 \mathrm{H}), 8.77-8.75(\mathrm{~d}, J=8 \mathrm{~Hz}, 0.5 \mathrm{H}), 8.30-8.28(\mathrm{~d}, J=8 \mathrm{~Hz}, 1 \mathrm{H}), 8.12-8.09(\mathrm{~m}, 3 \mathrm{H}), 7.94-7.84(\mathrm{~m}, 3 \mathrm{H})$, 7.63-7.58 (m, 6H), 7.42-7.36 (m, 1.5H), 7.24-7.21 (m, 1.5H), 7.08-7.06 (m, 1.5H), 6.94-6.88 (m, 1.5H), 6.55-6.46 (m, 1.5H), $5.38(\mathrm{~s}, 1 \mathrm{H}), 4.94(\mathrm{~s}, 2 \mathrm{H}) .{ }^{13} \mathrm{C}$ NMR (DMSO-d 6 ): $8182.09,182.03,167.52,164.38$, $163.64,163.54,163.49,163.17,161.17,161.06,157.95,157.23,156.88,147.37,143.29,132.91,132.52,132.16$, $132.10,131.59,131.25,130.53,129.13,128.89,128.68,128.13,127.80,127.75,126.46,123.54,123.40,120.97$, $118.75,118.13,110.08,108.45,105.45,105.33,105.10,98.87,98.73,93.68,93.46,66.72,65.59 . H R M S$ (ESI, $m / z)$ : calculated for $\mathrm{C}_{28} \mathrm{H}_{21} \mathrm{~N}_{2} \mathrm{O}_{6}[\mathrm{M}+\mathrm{H}]^{+} 481.1394$; found 481.1394 .

(E,Z)-2-((5-Hydroxy-4-oxo-2-phenyl-4H-chromen-7-yl)oxy)-N'-((2-hydroxy-5nitrobenzylidene)acetohydrazide (4o)

The product was obtained as a yellow powder. Yield (91\%). ${ }^{1} \mathrm{H}$ NMR (DMSO- $\left.d_{6}\right)(E: Z=1: 0.75)$ : $\delta 12.85-12.80(\mathrm{~m}, 1.75 \mathrm{H}), 11.97(\mathrm{bs}, 2 \mathrm{H}), 11.78(\mathrm{~s}, 1.5 \mathrm{H}), 8.64-8.54(\mathrm{~m}, 2.75 \mathrm{H}), 8.33(\mathrm{~s}, 1 \mathrm{H}), 8.15-8.10(\mathrm{~m}$, $5.25 \mathrm{H}), 7.64-7.55(\mathrm{~m}, 5.25 \mathrm{H}), 7.08-7.04(\mathrm{~m}, 3.25 \mathrm{H}), 6.90-6.86(\mathrm{~m}, 1.75 \mathrm{H}), 6.52-6.44(\mathrm{~m}, 1.75 \mathrm{H}), 5.39(\mathrm{~s}$, 2H), 4.89 (s, 1.5H). ${ }^{13} \mathrm{C}$ NMR (DMSO- $\left.d_{6}\right): \delta 182.08,182.03,168.28,164.42,163.71,163.61,163.46,162.04$, $161.14,161.04,157.20,144.30,139.91$, 138.65, 132.16, 132.10, 130.55, 129.12, 129.08, 126.73, 126.45, 123.37, $121.68,120.98,119.95,117.10,116.72,105.43,105.37,105.30,105.08,98.78,98.73,93.62,93.46,66.53,65.42$. HRMS (ESI, $m / z$ ): calculated for $\mathrm{C}_{24} \mathrm{H}_{18} \mathrm{~N}_{3} \mathrm{O}_{8}[\mathrm{M}+\mathrm{H}]^{+}$476.1088; found 476.1089.

\subsection{Biological Studies}

\subsubsection{Cell Lines and Cell Culture}

A panel of cancer cell lines, including breast (MDA-MB-231, BT20), brain (U251), and colon (HCT116), as well as a normal cell line (human mammary epithelial cells: HMECs), were grown as adherent monolayers in flasks with Dulbecco's Modified Eagle Medium (DMEM), supplemented with $10 \%$ fetal bovine serum (FBS) and 1\% penicillin and streptomycin in a humidified incubator with $5 \%$ $\mathrm{CO}_{2}$ at $37^{\circ} \mathrm{C}$.

\subsubsection{MTT Assay}

The (3-(4,5-dimethylthiazol-2-yl)-2,5-diphenyltetrazolium bromide) (MTT) assay was used to determine the cytotoxicity of the 15 chrysin derivatives in the above-mentioned cell lines. Briefly, cells were harvested with $0.05 \%$ trypsin, $2.21 \mathrm{mM}$ ethylenediaminetetraacetic acid (EDTA), $1 \times$ from Corning (Corning, NY, USA), and suspended at a final density of $5 \times 10^{3}$ cells/well. Cells were seeded

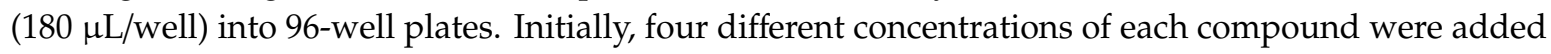
to find the compounds with the greatest antiproliferative efficacy in the MDA-MB-231 cell line $(0,1$, 10 , and $100 \mu \mathrm{M})$. Subsequently, eight different concentrations $(0.1,0.3,1,3,10,30$, and $100 \mu \mathrm{M})$ of each compound were added to the remaining cell lines mentioned above. After $68 \mathrm{~h}$ of incubation, 
$20 \mu \mathrm{L}$ of the MTT solution $(4 \mathrm{mg} / \mathrm{mL}$ ) were added to each well, and the plates were incubated for $4 \mathrm{~h}$. This allowed viable cells to biotransform the yellow-colored MTT into dark-blue formazan crystals. Subsequently, the medium was discarded, and $150 \mu \mathrm{L}$ of DMSO were added to each well to dissolve the formazan crystals. The absorbance was determined at $590 \mathrm{~nm}$ using a DTX 880 multimode detector (Beckman Coulter life sciences, IN, USA). The $\mathrm{IC}_{50} \pm \mathrm{SD}$ concentrations were calculated from three experiments performed in triplicate/duplicate. The $\mathrm{IC}_{50}$ values were calculated from the cell survival percentages obtained for each compound tested at different concentrations. Similarly, the cytotoxicity of the test compounds was compared to the normal cell line (HMEC).

\subsubsection{Cell Cycle, Apoptosis, and Mitochondrial Membrane Potential Analysis}

MDA-MB-231 cells were plated into 6-well plates at $2.5 \times 10^{5}$ cells/well. The cells were incubated with 0,5 , or $10 \mu \mathrm{M}$ of compounds $4 \mathrm{~g}$ or $4 \mathbf{i}$ and incubated for $12 \mathrm{~h}$. Next, the cells were trypsinized with $0.05 \%$ trypsin, $2.21 \mathrm{mM}$ EDTA, $1 \times$, washed, counted, and resuspended in $1 \mathrm{~mL}$ of ice-cold PBS. The cells then were stained with propidium iodide (PI) dye and incubated for at least $15 \mathrm{~min}$. The distribution of the cells in each cell cycle phase for the different concentrations was measured using a BD Accuri ${ }^{\mathrm{TM}}$ C6 flow cytometer from BD Biosciences (Becton-Dickinson, San Jose, CA, USA) and analyzed using FCS Express 5 plus De Novo software (Glendale, CA, USA).

MitoTracker Red and Alexa Fluor 488 annexin V kits for flow cytometry (Molecular Probes Inc., Invitrogen, Eugene, OR) were used to measure the mitochondrial membrane potential and apoptosis in MDA-MB-231 cells. Briefly, cells were seeded into 6-well plates and incubated with 0, 5, or $10 \mu \mathrm{M}$ of compounds $4 \mathrm{~g}$ and $4 \mathrm{i}$ for $12 \mathrm{~h}$. The cells were then lysed using $0.05 \%$ trypsin, $2.21 \mathrm{mM}$ EDTA, $1 \times$, counted, and $4 \mu \mathrm{L}$ of $10 \mu \mathrm{M}$ of the MitoTracker Red working solution were added to $1 \mathrm{~mL}$ of the harvested cells. The cells were incubated at $37^{\circ} \mathrm{C}$ with $5 \% \mathrm{CO}_{2}$ for $30 \mathrm{~min}$. The cells were washed once with PBS and resuspended in $100 \mu \mathrm{L}$ of the annexin binding buffer. The cell suspensions were incubated with $5 \mu \mathrm{L}$ of Alexa Fluor 488 annexin $\mathrm{V}$ for $15 \mathrm{~min}$. This was followed by the addition of $400 \mu \mathrm{L}$ of the annexin-binding buffer. Finally, flow cytometry was used to detect the fluorescence of stained cells at the following excitation/emission maxima: Alexa Fluor ${ }^{\circledR} 488$ annexin V: 499/521 nm; MitoTracker ${ }^{\circledR}$ Red: 579/599 nm with the BD Accuri ${ }^{\mathrm{TM}} \mathrm{C} 6$ flow cytometer from BD Biosciences (Becton-Dickinson, San Jose, CA, USA) and analyzed using FCS express 5 plus De Novo software (Glendale, CA, USA).

\subsubsection{Protein Expression Analysis Using Western Blot}

To measure the expression of Bak, cytochrome c, caspase-7, caspase-9, and mTOR, Western blotting was performed by lysing MDA-MB-231 cells using a lysis buffer $(50 \mathrm{mM}$ Tris- $\mathrm{HCl}, 150 \mathrm{mM} \mathrm{NaCl}$, $1 \mathrm{mM}$ EDTA, $0.5 \%$ NP-40, $1 \%$ Triton, $0.1 \%$ SDS) containing a protease inhibitor cocktail that consisted of Aprotinin, Bestatin, E-64, Leupeptin, and Pepstatin A (Sigma-Aldrich Life Science, St. Louis, MO, USA). The bicinchoninic acid (BCA) quantification assay was used to determine the protein levels in the cell extracts (G-BIOSCIENCES, St. Louis, MO, USA). The extracted proteins were loaded onto a $10-20 \%$ tris-glycine gel. After separation, the proteins were transferred from the gel onto a polyvinylidene difluoride (PVDF) membrane. The membranes were blocked using $5 \%$ milk in Tris-buffered saline Tween 20 for $30 \mathrm{~min}$ and incubated overnight with primary antibodies against Bak (1:1000), cytochrome C (1:1000), caspase-3 (1:1000), caspase 7 (1:1000), caspase 9 (1:1000), mTOR (1:1000), or B-actin (1:2000) in $5 \%$ BSA (bovine serum albumin) at $4{ }^{\circ} \mathrm{C}$. The next day, membranes were washed and incubated with horseradish peroxidase-labelled (HRP) anti-rabbit secondary antibody (1:5000 dilutions). The membrane was incubated with the antibody for an additional $1 \mathrm{~h}$. Subsequently, the membranes were washed and developed by Clarity Western ECL substrate (Bio-Rad; Hercules, CA, USA). Protein was detected using a ChemiDoc Imaging System (Bio-Rad). Densitometry analyses of the blots for the detected protein were quantified using the ImageJ software. Data was calculated as ratios of protein $/ \beta$-actin. 


\section{Conclusions}

In conclusion, a series of novel chrysin derivatives were designed, synthesized, and characterized. Upon screening these compounds for their antiproliferative efficacy in the TNBC cell line, MDA-MB-231, and normal breast HMEC cells, two compounds, $\mathbf{4} \mathbf{g}$ and $\mathbf{4 i}$, had the highest efficacy and selectivity towards MDA-MB-231 cells. Upon investigating the mechanism by which these compounds produce cytotoxicity, it was determined that $\mathbf{4} \mathbf{g}$ and $\mathbf{4 i}$ cause the death of MDA-MB-231 cells by inducing apoptosis, producing cell cycle arrest at the G2 phase, and activating the intrinsic apoptotic pathway. Physicochemical characterizations of these compounds suggested that they can be further optimized as potential anticancer compounds for TNBC cells. The compounds were determined to have some solubility issues that need to be overcome in the future design of additional compounds. Overall, our results suggest that $4 \mathrm{~g}$ and $4 \mathbf{i}$ could be suitable leads for developing novel compounds to treat TNBC.

Supplementary Materials: The following are available online, Figure S1: Chemical characterization of compounds 4a-4o.

Author Contributions: Conceptualization, B.A.A.-O., S.A.A. and A.K.T.; methodology, B.A.A.-O., S.A.A., H.R., S.M., N.H. and J.M.L.; software, S.M. and N.H.; validation, S.M. and N.H.; formal analysis, B.A.A.-O.; investigation, H.R., S.M., N.H., J.M.L.; resources, B.A.A.-O. and A.K.T.; data curation, B.A.A.-O., H.R., S.M., N.H. and J.M.L.; writing-original draft preparation, B.A.A. and S.M.; writing—review and editing, B.A.A.-O., S.A.A., S.M., S.K., M.F.B., C.R.A.J. and A.K.T.; visualization, A.K.T.; supervision, A.K.T.; project administration, A.K.T.; funding acquisition, B.A.A.-O., and A.K.T. All authors have read and agreed to the published version of the manuscript.

Funding: This work was funded by the Deanship of Scientific Research at Jordan University of Science and Technology (grant \# 20190360 to BAA). This manuscript has been supported, in part, by University of Toledo startup grants (F110760 to AKT) and Susan G. Komen Breast Cancer Foundation (CCR18548498 to AKT).

Acknowledgments: The authors acknowledge the financial support given by the Deanship of Research at the Jordan University of Science and Technology (grant \# 20190360 to BAA). The high-resolution mass spectrometry data were acquired from the Triad Mass Spectrometry Laboratory at the University of North Carolina at Greensboro, Greensboro, NC, USA. This manuscript has been supported, in part, by the University of Toledo startup grants (F110760 to AKT) and Susan G. Komen Breast Cancer Foundation (CCR18548498 to AKT).

Conflicts of Interest: The authors declare no conflict of interest.

\section{References}

1. Siegel, R.L.; Miller, K.D.; Jemal, A. Cancer statistics, 2019. CA Cancer J. Clin. 2019, 69, 7-34. [CrossRef]

2. Bianchini, G. Triple-negative breast cancer: Challenges and opportunities of a heterogeneous disease. Nat. Rev. Clin. Oncol. 2016, 13, 674-690. [CrossRef]

3. Scalbert, A.; Williamson, G. Dietary intake and bioavailability of polyphenols. J. Nutr. 2000, 130, $2073-2085$. [CrossRef] [PubMed]

4. Beecher, G.R. Overview of Dietary Flavonoids: Nomenclature, Occurrence and Intake. J. Nutr. 2003, 133, 3248-3254. [CrossRef] [PubMed]

5. Hodnick, W.F.; MllosavljeviĆ, E.B.; Nelson, J.H.; Pardini, R.S. Electrochemistry of flavonoids: Relationships between redox potentials, inhibition of mitochondrial respiration, and production of oxygen radicals by flavonoids. Biochem. Pharmacol. 1988, 37, 2607-2611. [CrossRef]

6. Namdeo, A.G.; Boddu, S.H.; Amawi, H.; Ashby, C.R., Jr.; Tukaramrao, D.B.; Trivedi, P.; Tiwari, A.K. Flavonoids as Multi-Target Compounds: A Special Emphasis on their Potential as Chemo-adjuvants in Cancer Therapy. Curr. Pharm. Des. 2020, 26, 1712-1728. [CrossRef] [PubMed]

7. Rapta, P.; Mišík, V.; Staško, A.; Vrábel, I. Redox intermediates of flavonoids and caffeic acid esters from propolis: An EPR spectroscopy and cyclic voltammetry study. Free Radic. Biol. Med. 1995, 18, 901-908. [CrossRef]

8. Williams, C.A.; Harborne, J.B.; Newman, M.; Greenham, J.; Eagles, J. Chrysin and other leaf exudate flavonoids in the genus Pelargonium. Phytochemistry 1997, 46, 1349-1353. [CrossRef]

9. Kuang, Y.H.; Patel, J.P.; Sodani, K.; Wu, C.P.; Liao, L.Q.; Patel, A.; Tiwari, A.K.; Dai, C.L.; Chen, X.; $\mathrm{Fu}, \mathrm{L} . \mathrm{W}$; et al. OSI-930 analogues as novel reversal agents for ABCG2-mediated multidrug resistance. Biochem. Pharmacol. 2012, 84, 766-774. [CrossRef] 
10. Cherkaoui-Tangi, K.; Lachkar, M.; Wibo, M.; Morel, N.; Gilani, A.; Lyoussi, B. Pharmacological studies on hypotensive, diuretic and vasodilator activities of chrysin glucoside from Calycotome villosa in rats. Phytother. Res. Int. J. Devoted Pharmacol. Toxicol. Eval. Nat. Prod. Deriv. 2008, 22, 356-361.

11. Wang, J.; Qiu, J.; Dong, J.; Li, H.; Luo, M.; Dai, X.; Zhang, Y.; Leng, B.; Niu, X.; Zhao, S. Chrysin protects mice from Staphylococcus aureus pneumonia. J. Appl. Microbial. 2011, 111, 1551-1558. [CrossRef]

12. Feng, X.; Qin, H.; Shi, Q.; Zhang, Y.; Zhou, F.; Wu, H.; Ding, S.; Niu, Z.; Lu, Y.; Shen, P. Chrysin attenuates inflammation by regulating M1/M2 status via activating PPAR $\gamma$. Biochem. Pharmacol. 2014, 89, 503-514. [CrossRef] [PubMed]

13. Romier, B.; Van De Walle, J.; During, A.; Larondelle, Y.; Schneider, Y.-J. Modulation of signalling nuclear factor- $\mathrm{KB}$ activation pathway by polyphenols in human intestinal Caco-2 cells. Br. J. Nutr. 2008, 100, 542-551. [CrossRef] [PubMed]

14. Wadibhasme, P.G.; Ghaisas, M.M.; Thakurdesai, P.A. Anti-asthmatic potential of chrysin on ovalbumin-induced bronchoalveolar hyperresponsiveness in rats. Pharm. Biol. 2011, 49, 508-515. [CrossRef]

15. Ahad, A.; Ganai, A.A.; Mujeeb, M.; Siddiqui, W.A. Chrysin, an anti-inflammatory molecule, abrogates renal dysfunction in type 2 diabetic rats. Toxicol. Appl. Pharmacol. 2014, 279, 1-7. [CrossRef] [PubMed]

16. Zanoli, P.; Avallone, R.; Baraldi, M. Behavioral characterisation of the flavonoids apigenin and chrysin. Fitoterapia 2000, 71, 117-123. [CrossRef]

17. Cardenas, M.; Marder, M.; Blank, V.C.; Roguin, L.P. Antitumor activity of some natural flavonoids and synthetic derivatives on various human and murine cancer cell lines. Bioorg. Med. Chem. 2006, 14, $2966-2971$. [CrossRef]

18. Amawi, H.; Ashby, C.R.; Samuel, T.; Peraman, R.; Tiwari, A.K. Polyphenolic Nutrients in Cancer Chemoprevention and Metastasis: Role of the Epithelial-to-Mesenchymal (EMT) Pathway. Nutrients 2017, 9, 911. [CrossRef]

19. Samarghandian, S.; Azimi Nezhad, M.; Mohammadi, G. Role of caspases, Bax and Bcl-2 in chrysin-induced apoptosis in the A549 human lung adenocarcinoma epithelial cells. Anti-Cancer Agents Med. Chem. 2014, 14, 901-909. [CrossRef]

20. Burke, J.F.; Schlosser, L.; Chen, H.; Kunnimalaiyaan, M. Chrysin induces growth suppression through apoptosis in neuroblastoma cells. J. Am. Coll. Surg. 2012, 215, S70. [CrossRef]

21. Zhang, T.; Chen, X.; Qu, L.; Wu, J.; Cui, R.; Zhao, Y. Chrysin and its phosphate ester inhibit cell proliferation and induce apoptosis in Hela cells. Bioorg. Med. Chem. 2004, 12, 6097-6105. [CrossRef] [PubMed]

22. Riedl, S.J.; Shi, Y. Molecular mechanisms of caspase regulation during apoptosis. Nat. Rev. Mol. Cell Biol. 2004, 5, 897-907. [CrossRef] [PubMed]

23. Shi, Y. Mechanisms of caspase activation and inhibition during apoptosis. Mol. Cell 2002, 9, 459-470. [CrossRef]

24. Zhu, Z.Y.; Wang, W.X.; Wang, Z.Q.; Chen, L.J.; Zhang, J.Y.; Liu, X.C.; Wu, S.P.; Zhang, Y.M. Synthesis and antitumor activity evaluation of chrysin derivatives. Eur. J. Med. Chem. 2014, 75, 297-300. [CrossRef]

25. Liu, Y.; Song, X.; He, J.; Zheng, X.; Wu, H. Synthetic derivatives of chrysin and their biological activities. Med. Chem. Res. 2014, 23, 555-563. [CrossRef]

26. Valdez-Calderón, A.; González-Montiel, S.; Martínez-Otero, D.; Martínez-Torres, A.; Vásquez-Pérez, J.M.; Molina-Vera, C.; Torres-Valencia, J.M.; Alvarado-Rodríguez, J.G.; Cruz-Borbolla, J. Synthesis, structural study and biological activity of new derivatives of chrysin containing a 2-mercaptopyridyl or 5-(trifluoromethyl)-2-mercaptopyridyl fragments. J. Mol. Struct. 2016, 1110, 196-207. [CrossRef]

27. Patel, R.V.; Mistry, B.; Syed, R.; Rathi, A.K.; Lee, Y.-J.; Sung, J.-S.; Shinf, H.-S.; Keum, Y.-S. Chrysin-piperazine conjugates as antioxidant and anticancer agents. Eur. J. Pharm. Sci. 2016, 88, 166-177. [CrossRef]

28. Xuan, H.-Z.; Zhang, J.-H.; Wang, Y.-H.; Fu, C.-L.; Zhang, W. Anti-tumor activity evaluation of novel chrysin-organotin compound in MCF-7 cells. Bioorg. Med. Chem. Lett. 2016, 26, 570-574. [CrossRef]

29. Al-Oudat, B.A.; Alqudah, M.A.; Audat, S.A.; Al-Balas, Q.A.; El-Elimat, T.; Hassan, M.A.; Frhat, I.N.; Azaizeh, M.M. Design, synthesis, and biologic evaluation of novel chrysin derivatives as cytotoxic agents and caspase-3/7 activators. Drug Des. Deve. Ther. 2019, 13, 423-433. [CrossRef]

30. Srinivasan, R.; Manoharan, S. Chemopreventive Potential of Chrysin in 7, 12-dimethylbenz (A) anthracene induced mammary carcinogenesis in sprague-dawley rats. J. Cell Tissue Res. 2011, 11, 2909. 
31. Lirdprapamongkol, K.; Sakurai, H.; Abdelhamed, S.; Yokoyama, S.; Athikomkulchai, S.; Viriyaroj, A.; Awale, S.; Ruchirawat, S.; Svasti, J.; Saiki, I. Chrysin overcomes TRAIL resistance of cancer cells through Mcl-1 downregulation by inhibiting STAT3 phosphorylation. Int. J. Oncol. 2013, 43, 329-337. [CrossRef] [PubMed]

32. Yang, B.; Huang, J.; Xiang, T.; Yin, X.; Luo, X.; Huang, J.; Luo, F.; Li, H.; Li, H.; Ren, G. Chrysin inhibits metastatic potential of human triple-negative breast cancer cells by modulating matrix metalloproteinase-10, epithelial to mesenchymal transition, and PI3K/Akt signaling pathway. J. Appl. Toxicol. 2014, 34, 105-112. [CrossRef] [PubMed]

33. Woo, K.J.; Jeong, Y.-J.; Park, J.-W.; Kwon, T.K. Chrysin-induced apoptosis is mediated through caspase activation and Akt inactivation in U937 leukemia cells. Biochem. Biophys. Res. Commun. 2004, 325, 1215-1222. [CrossRef] [PubMed]

34. Khoo, B.Y.; Chua, S.L.; Balaram, P. Apoptotic effects of chrysin in human cancer cell lines. Int. J. Mol. Sci. 2010, 11, 2188-2199. [CrossRef]

35. Putt, K.S.; Chen, G.W.; Pearson, J.M.; Sandhorst, J.S.; Hoagland, M.S.; Kwon, J.-T.; Hwang, S.-K.; Jin, H.; Churchwell, M.I.; Cho, M.-H. Small-molecule activation of procaspase-3 to caspase-3 as a personalized anticancer strategy. Nat. Chem. Biol. 2006, 2, 543-550. [CrossRef]

36. Peterson, Q.P.; Hsu, D.C.; Goode, D.R.; Novotny, C.J.; Totten, R.K.; Hergenrother, P.J. Procaspase-3 activation as an anti-cancer strategy: Structure- activity relationship of procaspase-activating compound 1 (PAC-1) and Its cellular co-localization with caspase-3. Eur. J. Med. Chem. 2009, 52, 5721-5731. [CrossRef]

37. Viegas-Junior, C.; Danuello, A.; da Silva Bolzani, V.; Barreiro, E.J.; Fraga, C.A.M. Molecular hybridization: A useful tool in the design of new drug prototypes. Curr. Med. Chem. 2007, 14, 1829-1852. [CrossRef]

38. Fortin, S.; Bérubé, G. Advances in the development of hybrid anticancer drugs. Expert Opin. Drug Discov. 2013, 8, 1029-1047. [CrossRef]

39. Zoete, V.; Daina, A.; Bovigny, C.; Michielin, O. SwissSimilarity: A Web Tool for Low to Ultra High Throughput Ligand-Based Virtual Screening; ACS Publications: Washington, DC, USA, 2016; pp. 1117-1121.

40. Delaney, J.S. ESOL: Estimating aqueous solubility directly from molecular structure. J. Chem. Inf. Comput. Sci. 2004, 44, 1000-1005. [CrossRef]

41. Daina, A.; Michielin, O.; Zoete, V. SwissADME: A free web tool to evaluate pharmacokinetics, drug-likeness and medicinal chemistry friendliness of small molecules. Sci. Rep. 2017, 7, 42717. [CrossRef]

42. Capuzzi, S.J.; Muratov, E.N.; Tropsha, A. Phantom PAINS: Problems with the Utility of Alerts for P an-A ssay IN terference Compound, S.J. Chem. Inf. Model. 2017, 57, 417-427. [CrossRef] [PubMed]

43. Ricci, M.S.; Zong, W.-X. Chemotherapeutic approaches for targeting cell death pathways. Oncologist 2006, 11, 342. [CrossRef] [PubMed]

44. Elmore, S. Apoptosis: A review of programmed cell death. Exp. Toxicol. Pathol. 2007, 35, 495-516. [CrossRef] [PubMed]

45. Levi, C.A.; Ejere, V.C.; Asogwa, C.N.; Iweh, P.; Nwatu, K.U.; Levi, U.E. Apoptosis: Its physiological implication and therapeutic possibilities. J. Pharm. Biolo Sci. 2014, 9, 38-45. [CrossRef]

46. Yang, J.; Liu, X.; Bhalla, K.; Kim, C.N.; Ibrado, A.M.; Cai, J.; Peng, T.-I.; Jones, D.P.; Wang, X. Prevention of apoptosis by Bcl-2: Release of cytochrome c from mitochondria blocked. Science 1997, 275, 1129-1132. [CrossRef]

47. Ouyang, L.; Shi, Z.; Zhao, S.; Wang, F.T.; Zhou, T.T.; Liu, B.; Bao, J.K. Programmed cell death pathways in cancer: A review of apoptosis, autophagy and programmed necrosis. Cell Prolif. 2012, 45, 487-498. [CrossRef]

48. Mariño, G.; Kroemer, G. Mechanisms of apoptotic phosphatidylserine exposure. Cell Res. 2013, $23,1247$. [CrossRef]

49. Vermes, I.; Haanen, C.; Steffens-Nakken, H.; Reutellingsperger, C. A novel assay for apoptosis flow cytometric detection of phosphatidylserine expression on early apoptotic cells using fluorescein labelled annexin V. J. Immunol. Methods 1995, 184, 39-51. [CrossRef]

50. Manivannan, E.; Amawi, H.; Hussein, N.; Karthikeyan, C.; Fetcenko, A.; Narayana Moorthy, N.S.H.; Trivedi, P.; Tiwari, A.K. Design and discovery of silybin analogues as antiproliferative compounds using a ring disjunctive-Based, natural product lead optimization approach. Eur. J. Med. Chem. 2017, 133, 365-378. [CrossRef] 
51. Amawi, H.; Hussein, N.; Boddu, S.H.S.; Karthikeyan, C.; Williams, F.E.; Ashby, C.R., Jr.; Raman, D.; Trivedi, P.; Tiwari, A.K. Novel Thienopyrimidine Derivative, RP-010, Induces beta-Catenin Fragmentation and Is Efficacious against Prostate Cancer Cells. Cancers 2019, 11, 711. [CrossRef]

52. Karthikeyan, C.; Amawi, H.; Viana, A.G.; Sanglard, L.; Hussein, N.; Saddler, M.; Ashby, C.R., Jr.; Moorthy, N.; Trivedi, P.; Tiwari, A.K. 1H-Pyrazolo[3,4-b]quinolin-3-amine derivatives inhibit growth of colon cancer cells via apoptosis and sub G1 cell cycle arrest. Bioorg. Med. Chem. Lett. 2018, 28, 2244-2249. [CrossRef] [PubMed]

53. Amawi, H.; Hussein, N.A.; Karthikeyan, C.; Manivannan, E.; Wisner, A.; Williams, F.E.; Samuel, T.; Trivedi, P.; Ashby, C.R., Jr.; Tiwari, A.K. HM015k, a Novel Silybin Derivative, Multi-Targets Metastatic Ovarian Cancer Cells and Is Safe in Zebrafish Toxicity Studies. Front. Pharmacol. 2017, 8, 498. [CrossRef]

54. Balaji, N.V.; Ramani, M.V.; Viana, A.G.; Sanglard, L.P.; White, J.; Mulabagal, V.; Lee, C.; Gana, T.J.; Egiebor, N.O.; Subbaraju, G.V.; et al. Design, synthesis and in vitro cell-based evaluation of the anti-cancer activities of hispolon analogs. Bioorg. Med. Chem. 2015, 23, 2148-2158. [CrossRef] [PubMed]

55. Karthikeyan, C.; Amawi, H.; Ashby, C.R., Jr.; Khare, V.M.; Jones, V.; Hari Narayana Moorthy, N.S.; Trivedi, P.; Tiwari, A.K. Novel 3-((2-chloroquinolin-3-yl)methylene)indolin-2-one derivatives produce anticancer efficacy in ovarian cancer in vitro. Heliyon 2019, 5, e01603. [CrossRef] [PubMed]

56. Amawi, H.; Karthikeyan, C.; Pathak, R.; Hussein, N.; Christman, R.; Robey, R.; Ashby, C.R., Jr.; Trivedi, P.; Malhotra, A.; Tiwari, A.K. Thienopyrimidine derivatives exert their anticancer efficacy via apoptosis induction, oxidative stress and mitotic catastrophe. Eur. J. Med. Chem. 2017, 138, 1053-1065. [CrossRef]

57. Amawi, H.; Ashby, C.R., Jr.; Tiwari, A.K. Cancer chemoprevention through dietary flavonoids: What's limiting? Chin. J. Cancer 2017, 36, 50. [CrossRef]

58. Westphal, D.; Dewson, G.; Czabotar, P.E.; Kluck, R.M. Molecular biology of Bax and Bak activation and action. BBA-Mol. Cell Res. 2011, 1813, 521-531. [CrossRef]

59. Shamas-Din, A.; Kale, J.; Leber, B.; Andrews, D.W. Mechanisms of action of Bcl-2 family proteins. CSH Perspect. Biol. 2013, 5, a008714. [CrossRef]

60. Delbridge, A.R.; Grabow, S.; Strasser, A.; Vaux, D.L. Thirty years of BCL-2: Translating cell death discoveries into novel cancer therapies. Nat. Rev. Cancer 2016, 16, 99. [CrossRef]

61. Lamkanfi, M.; Kanneganti, T.-D. Caspase-7: A protease involved in apoptosis and inflammation. Intl. J. Biochem. Cell Boil. 2010, 42, 21-24. [CrossRef] [PubMed]

62. Choe, H.; Kim, J.; Hong, S. Structure-based design of flavone-based inhibitors of wild-type and T315I mutant of ABL. Bioorg. Med. Chem. Lett. 2013, 23, 4324-4327. [CrossRef] [PubMed]

Sample Availability: Samples of the compounds $4 \mathrm{a}, \mathbf{4 g}, \mathbf{4 i}$ and $4 \mathrm{o}$ are available from the authors on request.

(C) 2020 by the authors. Licensee MDPI, Basel, Switzerland. This article is an open access article distributed under the terms and conditions of the Creative Commons Attribution (CC BY) license (http://creativecommons.org/licenses/by/4.0/). 